Pamiętnik Literacki 2015, 4, s. 133-169

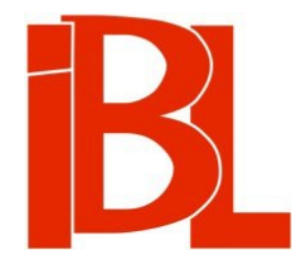

\title{
Inedita krytyczne Tadeusza Makowieckiego
}

\author{
oprac. Krystyna Jakowska
}




\title{
2. $\begin{array}{lllllllllllllllllll} & \mathrm{M} & \mathrm{A} & \mathrm{T} & \mathrm{E} & \mathrm{R} & \mathrm{I} & \mathrm{A} & € & \mathrm{Y} & \mathrm{I} & \mathrm{N} & \mathrm{O} & \mathrm{T} & \mathrm{A} & \mathrm{T} & \mathrm{K} & \mathrm{I}\end{array}$
}

Pamiętnik Literacki CVI, 2015, z. 4, PL ISSN 0031-0514

\section{INEDITA KRYTYCZNE TADEUSZA MAKOWIECKIEGO}

\author{
Opracowała \\ KRYSTYNA JAKOWSKA Uniwersytet w Białymstoku
}

Tadeusz Makowiecki rozpoczął swój życiorys historyka literatury, edytora i historyka sztuki w latach dwudziestych ubiegłego wieku, w latach trzydziestych był już badaczem nagradzanym i znanym. Związany ze środowiskiem „Marchołta”, członek elitarnego KLiN-u, wicedyrektor, a za czasów okupacji skuteczny obrońca księgozbioru Biblioteki Uniwersytetu Warszawskiego, zmarł jako profesor historii literatury - ledwie powołany i szybko ze względów politycznych odsunięty od wykładania - w Toruniu w maju 1952. Miał zaledwie 52 lata. Był cenionym badaczem Norwida, autorem dwóch książek o Wyspiańskim (nagroda PAU w 1936 roku), a także teoretykiem wzajemnej relacji sztuk: literackiej, muzycznej i plastycznej. W dziedzinie historii sztuki, którą też uprawiał, seria jego artykułów o Tylmanie z Gameren posłużyła m.in. do ustalania autorstwa dzieł tego barokowego architekta. Był też poeta i pozostawił poza lirykami poemat Pani Zosia, poruszające dopełnienie Mickiewiczowskiej epopei.

Pamięć o Tadeuszu Makowieckim wśród literaturoznawców trwa; mimo upływu lat jego dorobek okazuje się bliski współczesności, mnożą się niezależne od siebie inicjatywy zbierania i publikowania, $z$ komentarzami, jego prac. Niedawno Andrzej Hejmej ogłosił część teoretyczną wydanej pośmiertnie książki Makowieckiego Muzyka $w$ twórczości Wyspiańskiego ${ }^{1}$. Przedrukowany tekst uznał za ,jeden z najciekawszych i nadal inspirujących" ${ }^{2}$. Rozproszone prace Makowieckiego o Norwidzie, również cenione bardzo wysoko ${ }^{3}$, zostały zebrane przez badaczy z KUL-u i opublikowane w osobnym tomie dwa lata temu ${ }^{4}$. Makowieckiemu wreszcie poświęcona

1 T. Makowi e c ki, Poezja a muzyka. W zb.: Muzyka w literaturze. Antologia polskich studiów powojennych. Red. A. Hejmej. Kraków 2002.

2 A. Hejmej, wstęp w zb.: jw., s. XII.

3 Zob. P. Chlebows ki, O sytuacji w badaniach nad Norwidem. Preliminaria. W zb.: Jak czytać Norwida? Postawy badawcze, metody, weryfikacje. Red. B. Ku c z e r a-C h a ch uls ka, J. Trzcionka. Warszawa 2008, s. 54: „trudno wyobrazić sobie współczesną norwidologię bez wnikliwych uwag Wacława Borowego, studiów Zofii Szmydtowej i genialnych analityczno-syntetycznych rozpraw Tadeusza Makowieckiego, tych, które powstały jeszcze przed drugą wojną światową" Chodzi m.in. o artykuły T. Makowi e cki e go Młodzieńcze poglądy Norwida na sztukę, Norwid a rok 1848, Norwid wobec powstania styczniowego.

4 T. M a k ow i e c ki, Poeta i myśliciel. Rozprawy i szkice o Norwidzie. Zebr., oprac. E. C hle b ows ka, W. Tor uń. Lublin 2013. 
jest część niedawno wydanej książki Marka Busia o najwybitniejszych „norwidystach" ${ }^{5}$. Niewielu chyba jest badaczy podobnie entuzjastycznie odkrywanych.

A jednak, najprawdopodobniej dlatego, że krytykiem literatury sobie współczesnej bywał Makowiecki rzadko i pozostawił - ilościowo - niewiele, jako krytyk jest całkowicie zapomniany. Nie ma nawet jego nazwiska w książce Krzysztofa Dybciaka o personalistycznej krytyce literackiej lat trzydziestych, co zreszta dałoby się wytłumaczyć, skoro autor ograniczył się do pokolenia 1910, a Makowiecki był o 10 lat starszy. Pomija go także Henryk Markiewicz w książce Od Tarnowskiego do Kotta (2010) - co może nie dziwi, jeśli mowa tu o krytykach $z$ wielkim ilościowym dorobkiem. Nie znajdujemy jednak nazwiska Makowieckiego również w serii 2 Badań nad krytyka literacka pod redakcją Krzysztofa Dybciaka i Michała Głowińskiego (1984); brak też najlżejszej wzmianki o nim w tomie Przypadki krytyczne. Studia o krytyce, życiu oraz świadomości literackiej po r. 1918 pod redakcją Dariusza Nowackiego i Krzysztofa Uniłowskiego (2007), podobnie jak w książce Dariusza Skórczewskiego Spory o krytykę literacka $w$ Dwudziestoleciu międzywojennym (2002). Przypomnienie Makowieckiego jako krytyka literatury współczesnej może być zatem dla wielu niespodzianką. Chcemy tu przywołać jego artykuły, przeglądy i recenzje, które stanowią nieznaną w tej chwili gałąź jego twórczości: zapomniane w foliałach czasopism, nieliczne, ale ciekawe i często bardzo piękne teksty krytyczne, dotyczace współczesnej mu prozy i - sporadycznie - dramaturgii.

$Z$ pewnością wydać należy całość tej krytyki, publikowanej w prasie międzywojennej. To, jak się należy spodziewać, kwestia przyszłości. Na razie przypomnimy inedita, pisane już po wojnie.

Formułując tu sądy o charakterystycznych rysach krytyki Makowieckiego, obejmujemy jednak myślą całość jego dorobku krytycznego. Wszędzie bowiem, zarówno w tekstach przed-, jak i powojennych, uderza czytelnika to samo osobiste piętno, wyrazista i ujmująca autorska sygnatura.

Co w literaturze interesowało Makowieckiego-krytyka? Ciekawe, że sam będąc poeta - i zajmując się poetami (obok Norwida i Wyspiańskiego także Słowackim i Mickiewiczem), jako krytyk współczesności pisywał głównie o prozie. Wysoko cenił Berenta oraz Żeromskiego, Dąbrowska była mu obca, bardzo wielu pisarzy nie zauważał. To, czy coś $\mathrm{w}$ prozie jest nowe, czy tradycyjne, nie obchodziło go wcale. Ani to, jakie pisarz czy dzieło reprezentuje kierunki estetyczne. Był najdalszy od porządkowania i segregowania. Interesował go ujawniony w dziele człowiek oraz jego propozycja moralna i estetyczna, mierzona aktualną przydatnością społeczną. Był zatem krytykiem-personalistą; zreszta również w swej pracy badawczej koncentrował się na tych właśnie, personalistycznych $z$ ducha, aspektach ${ }^{6}$. Podobnie jak Borowy nie tworzył syntez, tylko „zafascynowany tym, co jednostkowe i niepowtarzalne" ${ }^{7}$, opisowi tych jakości - zarówno w nauce, jak w krytyce - podporząd-

$5 \quad$ M. Bu ś, Norwidyści: Miriam-Cywiński-Borowy-Makowiecki-Wyka. Konteksty. Kraków 2008.

6 W zakończeniu swej rekonstrukcji metody badawczej Makowieckiego-norwidologa Buś (ibidem, s. 156) konkluduje: „To, co Makowieckiego w Norwidzie intryguje najbardziej, to jego osobowość: artystyczna przede wszystkim, ale też polityczna, społeczna, etyczna, po prostu ludzka”.

7 M. Głow ińs ki, Wacław Borowy - artyzm i umysłowość. W zb.: Zatajony artysta. O Wacławie Borowym 1890-1950. Wybór szkiców i wspomnień A. Bi e r n a cki. Lublin 2005, s. 194. 
kowywał swój bezbłędny, bogaty a utajony analityczny warsztat. Być może dlatego również jego dorobek krytyczny w większości pozostaje nietknięty przez upływający czas.

Skąd w ogóle krytyka współczesna w jego dziele, związanym przecież ze sztuką i literaturą dawniejszych wieków?

W Dwudziestoleciu - choć wykształcił się już zawód krytyka - często uczeni bywali również krytykami; możemy więc w „Tygodniku Ilustrowanym” z r. 1932 przeczytać recenzję Aciaków z I A Kadena-Bandrowskiego pióra samego Juliusza Kleinera, „krytykiem na katedrze” był Wacław Borowy, naukę i krytykę uprawiał Karol Wiktor Zawodziński. Nie inaczej było z Makowieckim. Krytyka wprawdzie zawsze pozostawała na marginesie jego prac historycznoliterackich i edytorskich, ale jego obecność w ówczesnym życiu literackim zaznaczała się stosunkowo mocno. Bywał recenzentem takich pism jak współzakładany przezeń „Przegląd Warszawski” oraz „Rocznik Literacki”, później współpracował przede wszystkim z „Pamiętnikiem Warszawskim”, ale i z „Pamiętnikiem Literackim”, „Polonista” i efemerycznym „Znakiem”, zdarzało mu się publikować w „Tygodniku Ilustrowanym”, wiersze ogłaszał w „Marchołcie” - a gdy przed samą drugą wojną to elitarne, wysoko cenione pismo musiało zniknąć, objął redakcje po Stefanie Kołaczkowskim i zdążył wydać trzy numery kwartalnika pod zmienionym tytułem „Glossy”. Opracowywał tam również przeglądy czasopism niemieckojęzycznych. Po wojnie należał do zespołu redakcyjnego „Pamiętnika Literackiego”, publikował ponadto w „Tygodniku Powszechnym” i lokalnym „Jantarze”. Pozostawił też kilka szkiców w maszynopisie.

Osobowość Makowieckiego-krytyka ukształtowało środowisko „Marchołta”; szczególnie zaś, jak można sądzić z istotnych cech postawy krytycznej tego twórcy, przyjaźnie z Kołaczkowskim i z Borowym, z którymi dzielił norwidowskie w genezie przekonanie o ważności wrażenia estetycznego, ale i o konieczności podporządkowania owego wrażenia wartościom etycznym. Zarówno Borowy, jak Makowiecki byli norwidologami - i z Norwida wzięte było motto „Marchołta”: „Piękno bez prawdy zatęchnie w samolubstwie czasu lub koterii”.

Personalistyczne nastawienie Makowieckiego spowodowało, że posługiwał się on w swojej krytyce przede wszystkim portretem - dzieła lub autora. W tym portrecie takiej samej wagi był aspekt estetyczny dzieła, jak aspekt moralny - w najszerszym rozumieniu tego słowa. Współistnienie owych dwu kryteriów Makowiecki obserwował z sympatią w krytyce Zawodzińskiego, ceniąc go zarówno za wrażliwość osobistą „na każdy okruch piękna”, jak „nie mniej mocne poczucie społecznego

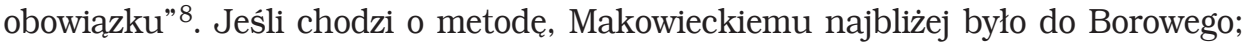
zapewne podpisałby się pod syntetycznym obrazem idealnego krytyka, jaki nakreślił Borowy pisząc o Kołaczkowskim: otóż ważne, aby krytyk posługiwał się „metodą historyczną i ścisłymi sposobami analizy” - celem jednak nie ma być ani „obraz historyczno-literacki, ani rozbiór formalno-estetyczny”, tylko „patos najgłębszych przeżyć moralnych i metafizycznych" ${ }^{9}$.

Gdy chodzi o wybór języka krytycznego, Makowiecki pozostawał bliski poezji.

8 T. Makowi e cki, Wspomnienie o K. W. Zawodzińskim. „Pamiętnik Literacki” R. 40, 1952.

9 Cyt. za: J. Ci es zkowski, Wacław Borowy. Krytyk - historyk literatury - artysta. Warszawa 1980, s. 129. 
Tam, gdzie po delikatnie przeprowadzonym, jakby trochę schowanym, ale nad wyraz precyzyjnym dyskursie analitycznym trzeba było sformułować wniosek, posługiwał się obrazem. Tam, gdzie chciał nawiązać kontakt z czytelnikiem, posługiwał się językowym żartem. Toteż czytanie jego krytyk nie różni się od czytania literatury. Autor odsłania się w swoim języku - cały czas pozostajemy w kręgu jego osobowości. A była to osobowość niezmiernie pociagająca, o czym świadczą liczne wspomnienia o nim ${ }^{10}$ i co mogą potwierdzić ci spośród żyjących, którzy go znali i pamiętają urok ciepła, dobroci i z lekka absurdalnego humoru. O zasadniczej roli poezji jako podłoża twórczości Makowieckiego pisał Henryk Elzenberg: „w samej głębi duszy [był on], poetą - i to była, wolno przypuszczać, owa esencjalna rezerwa, z której czerpał treść i impulsy do swych ściślej intelektualnych poczynań" ${ }^{11}$. Z owej „esencjalnej rezerwy” pochodził w jakiejś mierze także używany przezeń język.

Przyjrzyjmy się bliżej najistotniejszemu składnikowi tego języka: poetyckiemu obrazowi. Bierze się on $\mathrm{z}$ wielu wyobraźniowych źródeł, $\mathrm{z}$ różnych bardzo tworzyw, co jest odbiciem wszechstronności samego autora. W obrazach, które unaocznić maja cechy literackiego tekstu, widać wyobraźnię historyka sztuki - zwłaszcza architektury. Ale też fascynację muzyka. A także możliwościami potocznego słowa. Obraz przy tym staje sie podstawa, rudymentem wywodu. Oto - dla ilustracji początek szkicu o Żywych kamieniach Berenta:

Żywym kamieniem u progu szarych, trudnych, powojennych dni legło dzieło Berenta. Dni są wciąż nadto groźne, a dzieło nadto wielkie, by nie przestać pytać, co mówi kamień żywy, o czym świadczy, dokąd woła?

Kiedyś w poprzek drogi pracy pozytywnej, fachowej, organicznej rzucił autor veto swego Fachowca: nie tędy droga! Tędy droga do zatracenia wolności i godności człowieka: tu kończy się człowiek. Potem na drogę do tajemniczych gajów sztuki czystej, do absolutu artystycznych przeżywań, zwalił wielkie swe Próchno. Tędy droga do zagubienia prawdy życia - tu też kończy się człowiek.

Wreszcie na drodze, idącej przez grząski moczar fermentów roku 1905, wkopał tamę Oziminy. Nie tędy droga! Nie przez moczar, który wchłania żywych w głąb zapadającej się, strupieszałej przeszłości albo w świat podziemnej, kreciej roboty, cuchnacej zgnilizną Wschodu, mrokiem Bizancjum. Jedna tylko wąska ścieżka Wandy-Demeter, wchodzącej do otchłani narodu, zostaje wolna; przed nia jedyną nie kładzie się wola Berenta twardą, żelazną barierą sprzeciwu.

Ale przeciw tym trzem przeczeniom, tym trzem: „Nie!”, zamkniętym w trzech powieściach - domagało się głosu pragnienie: „Tak!”

Na wprost oblicza ludzi fachowych, zmaszynowanych, uprzemysłowionych trzeba było dźwignąc ludzi po prostu żywych: w obliczu artystów zakłamanych, postrzępionych, zdartych, zaropiałych - ukazać artystów prostych; wreszcie przeciw ludziom ciemnym, zatrutym drobnoojczyźnianymi i płaskospołecznikowskimi mętami życia trzeba było postawić ludzi jasnych, prawdziwych w rzeczach wiecznych. Wszystkie przeczenia, wyrosłe z długiej, twardej, zaciętej walki myśli, żądały zrównoważenia w potwierdzeniu.

To jedna sprawa Żywych kamieni.

Drugą było przeżycie do dna wiedzy radosnej tańczącego mędrca Zaratustry i jego woli mocy potężnej, nadczłowieczej i jego pogardy dla mieszczuchów płaskogłowych i płaskoserdecznych z cudacznego miasta, zwanego „Pstrą Krową, pstrokacizną, pustką hałaśliwą.

Pośrednie to tylko ogniwo do trzeciego, ważniejszego o wiele. Było nim dosłyszenie kroku dwu nadchodzących mocy-zmor, groźniejszych może niż zbliżający się huk dział. Jedna moc - straszydło - to przeciwne śmiałemu odrywaniu się stopy biegnącej przyrośnięcie brzuchem do ziemi, rozrost paszczy

10 Zob. wspomnienia zawarte w książce Tadeusz Makowiecki (Red. nauk. H. Elzen berg. Toruń 1956), zwłaszcza świetny szkic H. E l z e n b e r g a Tadeusz Makowiecki-artysta i teoretyk sztuki. 
i szczęk, i trawiącego kadłuba. Druga siła - to „acedia”, martwota i otępienie duszy, zdrewnienie włókien nerwowych i ponurość zrezygnowana.

$[\ldots]$

Wypatrywacz groźnych chimer nadlatujących z Jutra musiał i te potwory zobaczyć i zapragnął je ujarzmić za kratami powieści. I to jest trzecia sprawa i trzeci zrąb pod gmach Żywych kamieni. Wyznaczały one poniekąd czwarty węgieł budowy. Twórca, który chciał dać światu ludzi jasnych, prostych i wielkich, artystów prawdziwych, wiecznych, który chciał rozsnuć wszystko bogatym rytmem wiedzy radosnej, przekornej złym chimerom - nie mógł wprowadzić ich w gorączkowe, posępne, chaotyczne „dzisiaj” okołowojennego dnia, w środowisko ludzi scherlałych, przegryzionych, rozbitych. Musiał odbić ku innym czasom: wylądował $\mathrm{w}$ średniowieczu ${ }^{12}$.

Tu urywamy, pozostawiając już następujący dalej wspaniały obraz sztuki średniowiecza - po to, by przypatrzyć się temu, co zacytowane.

Metaforyczny akord początkowy, sugerujacy aktualność tej nieco przecież przebrzmiałej w 1930 roku powieści, i dwa następne akapity, dotyczące znaczeń powieści poprzednich, są wyłącznie obrazowe, obywają się bez pojęciowych werbalizacji - a pozostaja semantycznie wyraziste i celne. Wreszcie w czwartym, dobitnie krótkim akapicie pokazany jest obrazowo sens Żywych kamieni. Ciąg dalszy stanowi rozbudowę tego początku - to kompozycja „rozkwitająca”, o utrzymanym rytmicznym układzie trójkowym, przechodzącym w czwórkowy. Ta dbałość o rytm - nie przypadkowy przecież, ale wynikający z porządku materiału i myśli, zachowana jest do końca. Nie miejsce tu na dalsze szczegółowe analizy. Zauważyć jednak trzeba, że owemu „muzycznemu” rytmowi sprzyja inne jeszcze, dodane w drugiej części szkicu, uporządkowanie, tym razem wzięte z plastyki. Oto na skutek natłoku powieściowych scen:

Czytelnik z początku jest jak w lesie, ale rychło spostrzega, że jest w lesie kolumn gotyckich, kolumn, które się wiążą czołami w całość jednolitą, precyzyjną, choć skomplikowaną, ścisłą, jak geometrycznie ścisłe są związania łuków i sklepień katedr gotyckich ${ }^{13}$.

Wciąż zatem znajdujemy się w katedrze: nie o wątkach się mówi, lecz o nawach, przy czym „nawa środkowa, poświęcona czujnej, bezwzględnej niezawisłości ducha, wyznacza oś całego dzieła Berenta” - dalszy zaś bieg myśli krytyka zmierza do modlitwy płatnerza, która ,jest kluczem sklepiennym całego gotyckiego dzieła” pisarza ${ }^{14}$. Poetycki charakter tekstu krytycznego umożliwia autorowi posłużenie się ekfrazą. Tezy krytyczne, wyrażone językiem muzyki i plastyki, wyrafinowana kompozycja całości - taki szkic mógł wyjść tylko spod ręki Tadeusza Makowieckiego.

Popatrzmy teraz na obraz nie jako na budulec wywodu. Zaletą indywidualnego obrazu, zwykle umieszczanego w istotnym miejscu rozważań i całkowicie zastępującego wyraz słowny, jest, poza lapidarnością, jasność nie werbalizowanego sensu. Ta wiara w semantyczne możliwości obrazu idzie u Makowieckiego w parze $z$ wymaganiami wobec precyzyjności własnego dyskursu: obraz go „tylko” wieńczy. Dyscyplina wywodu chroni badacza-krytyka-poetę przed niebezpieczeństwami nadużycia obrazu. Owa dyscyplina zbliża - również w dziedzinie języka - krytykę Ma- 
kowieckiego do prac Borowego. Nie darmo ten ostatni wysoko cenił pisarstwo Makowieckiego, w którym, jak obserwował, wnioski „wysnute z delikatnej sieci przesłanek, mają w czystości swego wykończenia coś z charakteru dobrze rozwiązanych zadań perspektywicznych" ${ }^{15}$.

Obraz w krytyce Makowieckiego odgrywa zasadniczą rolę, gdy trzeba zaprezentować sens szczególnie ulotny. Zobaczmy, jak w recenzji dramatów Szaniawskiego rozbudowane obrazowe porównanie nadaje wyrazistość jakości tak nieuchwytnej, jak często obserwowana u pisarza „papierowość”:

W każdym dziele sztuki jest coś ze stylizacji. A stylizacje są dwie. Jedna wychodzi od rzeczywistości. Ta, w sztuce zdobniczej na przykład, przeanalizuje kształt liścia pewnego czy kwiatu, pozna rozgałęzienia nerwów, wykrój płatków i wtedy, układając je, skracając jedne linie, nieco wyginając inne zamknie wszystko w kształt skończony, w system linij, poddanych jakiejś figurze geometrycznej. Drugi rodzaj - przeciwnie - wychodzi $z$ form abstrakcyjnych. Ten w dekoracjach wpisze w koło czy trójkąt szereg linij prostych i krzywych, odcinków kół i owali, i dopiero ów system linij cyrklem nakreślonych i związanych w jedną całość pocznie z lekka giąc i odkształcać, i powoli zbliżać do rzeczywistości kwiatu czy liścia. Wyniki obu działań są bardzo sobie bliskie, ale jakoś, niemal nieuchwytnie, odczuć można w dziele pierwszym większą świeżość i miękkość, w drugim mocniejszą poprawność.

W literaturze takim liściem czy kwiatem bywa człowiek, a zamiast kół i rombów mamy problemy filozoficzne, psychologiczne, społeczne. I mimo zbliżeń i pokrewieństw poznać przecież można, w których utworach przejrzenie człowieka na wskroś otwiera widoki na prawdę i prawa poza nim, a w których formy owych praw dopiero wykładane są żywą treścią, historią człowieka.

Komedie Szaniawskiego należą do drugiego typu. Mimo najbardziej kapryśnej linii akcji, charakterów, słów odczuwa się granice ornamentu, wytyczne kierunki abstraktu. Stąd zarzut „papierowości”, który czasem pada w stronę tych utworów $[\ldots]^{16}$.

Obraz ponadto pozwala jednym wyrażeniem uchwycić charakter tekstu: np. gdy powagę gotyckiego witraża, która nacechowany jest Żeglarz, przeciwstawia krytyk niepowadze kalejdoskopu w Ptaku czy gdy w interpretacji tegoż Żeglarza posługuje się rozbudowanym obrazem dwóch szal wagi, czy wreszcie - rekonstruując sens Adwokata i róż wykorzystuje metaforę muzyczną. Skromna recenzja staje się tu prawdziwym dziełem sztuki.

Dodatkowym składnikiem specyfiki językowej krytycznego pisarstwa Makowieckiego jest potoczność. To ona bywa niekiedy źródłem językowego dowcipu - albo szczególnego estetycznego efektu swojskości. Lub też - stworzenia obrazu o potocznej proweniencji. Na ogół bywa tym wszystkim naraz. Jak w zdaniu o Boyu, któremu według krytyka nie można dyktować przedmiotu translatorskiego zainteresowania: „trudno narzucać książki tłumaczowi-artyście [...]. Takie podrzutki wyrosłyby na pewno krzywo" ${ }^{17}$. W tok wywodu krytycznego potoczne wyrażenie włączone jest nie na jakimś miejscu poślednim! Bynajmniej, tu wyraża sedno myśli. Potoczność bywa też u Makowieckiego uderzającym efektem estetycznym, gdy ją pisarz łączy z „wysokim” stylistycznie, bo naukowym, dłuższym wywodem, jak w recenzji powieści o Słowackim autorstwa Juliana Wołoszynowskiego:

15 W. B or owy, Norwidiana 1925-1929. Cyt. za: Bu ś, op. cit., s. 155.

16 T. Makowi e cki, rec.: J. Szaniawski: Żeglarz; Ptak; Adwokat i róże. Warszawa 1930. „Pamiętnik Warszawski” 1930, z. 7, s. 73.

17 T. Ma kow i e c ki, Laureaci roku 1933 (Wacław Berent, Tadeusz Boy-Żeleński, Maria Dąrowska). „Rocznik Literacki” t. 2 (1933), s. 298. 
Powieść biograficzna nie jest pracą wdzięczną i łatwą. Nurt jej, płynący pozornie przez drogi już wyżłobione, napotyka groźne Scylle i Charybdy. Scylla jest - swoboda, stylizująca wszystkie linie; Charybda - wierność, która ogranicza się do ożywienia czerwoną kredką rysów powiększonych ze starej, wyblakłej fotografii. Dwa te niebezpieczeństwa grożą prawie nieuchronnie, gdy portretuje się z fotografii - biografii, a nie $\mathrm{z}$ żywego modelu czy tylko $\mathrm{z}$ fantazji. [...]

Julian Wołoszynowski pragnął uniknąć obu raf. Wrażliwość poetycka i pietyzm do osoby portretowanego nie pozwoliły mu dokomponować zagubionych fragmentów życia, przyprawić rąk Venus Milońskiej. Tażsama jednak wrażliwość nie zgadzała się na parafrazowanie Słowackiego, na powtarzanie „swoimi słowami” - scen i myśli z listów czy z raptularza poety, na kopiowanie oryginału. Tu owa antynomia artystyczna, stojąca u podstaw każdej rzetelnie pomyślanej powieści biograficznej, ukazała swe zezowate oczy ${ }^{18}$.

Drugim biegunem estetycznym jest patos; bywa, że to prosty wynik poetyckości w węższym znaczeniu tego słowa - jak choćby w tym fragmencie cytowanej już recenzji:

u Szaniawskiego wszystko odbywa się poza dobrem i złem, na wąskiej granicy, nie ustalonej jeszcze przez geometrów świata, między prawdą i złudą, między rzeczywistością i bajką, między dniem powszednim i świątecznym, między „tak” $\mathrm{i}$,inaczej”, pod znakiem gwiazd noszących nazwę - pi ę k no ${ }^{19}$.

Potoczność i patos - przeciwstawiając się sobie, jedno wzmacnia drugie - w rezultacie nadają tekstowi życie.

Pisarstwo krytyczne Makowieckiego cechuje często dowcip - ściszony, nigdy sam dla siebie, zawsze wyrastający z treści zdania i jej służący. Jak uśmiech czy błysk oczu przy opowiadaniu: „awans [Rykowa w wojsku] [...] może nawet nie [był] tak olśniewający, jak ten, który spotkał go niebawem, gdy z dziewiątego korpusu drugiej armii przeszedł do dziewiątej księgi Pana Tadeusza”; „ot, swoisty Pan Jowialski à la Strogonoff" 20 .

Cechą tego języka jest w rezultacie całkowita swoboda ujawniania pośrednio, poprzez język tylko, emocji krytycznych: od powagi przez ironię po żart. W tej swobodzie wyraża się skromność autora, nie wynoszącego się ponad czytelnika - owszem, stawiającego się z nim na równi. Podobnie jak to się działo na dyskusjach seminaryjnych, w których, jak wspominają byli studenci, profesor przyjmował rolę dyskutanta $^{21}$.

Należy też zauważyć, że wszystkie zalety sztuki krytycznej Makowieckiego odnaleźć można również w najnudniejszych, wydawałoby się, formach wypowiedzi - jak choćby w publikowanych w „Roczniku Literackim” sprawozdaniach i przeglądach (które na ogół mało kto traktuje jako dzieła sztuki krytycznej). Obdarzono tam Makowieckiego obowiązkiem corocznego referowania „literatury felietonowej”, której nie cenił i która go irytowała, czemu w swoich omówieniach dawał błyskotliwie, a potem już ze znużeniem, wyraz. Znacznie lepiej czuł się w sytuacjach, w których, obcując z prawdziwymi wielkościami, ujawnić mógł w pełni talent krytyczny - jak

T. Makowiecki, rec.: J. Wołoszynow ski, Stowacki. Powieść. Ze wstępem S. W a sylews k i e go. Poznań. „Pamiętnik Warszawski” 1929, z. 1, s. 227.

19 Makowiecki, rec.: Szaniaw ski: Żeglarz; Ptak; Adwokat i róże, s. 78.

20 Zob. publikowany tu szkic Kariera kapitana Rykowa $w$ literaturze polskiej, s. 141.

21 Zob. Z. Moł od có wn a, Makowiecki Tadeusz. Hasło w: Polski słownik biograficzny. T. 19, z. 2. Wrocław 1974. Zob. też wspomnienia Cz. Zgor zel s ki e go Przywołane z pamięci (Lublin 2006). 
w świetnym szkicu o laureatach nagrody państwowej w 1933 roku $^{22}$, gdzie u trzech - właściwie nieporównywalnych - osobowości pisarskich: Berenta, Boya i Dąbrowskiej, odkrył podobieństwo ich stosunku do kultury współczesnej.

Znakomite sa portretowe wspomnienia Makowieckiego o Borowym-bibliotekarzu, o Gubrynowiczu, o Zawodzińskim. Z kolei artykuły-studia na temat wybranych tekstów Żeromskiego, Szaniawskiego czy Berenta - są w tej krytyce formą ulubioną, dającą też najwięcej możliwości, najświetniejszą.

Wszystkie krytyki Tadeusza Makowieckiego warte sa przypomnienia i wydobycia z bibliotecznego kurzu; zwłaszcza że czasopisma, w których je drukował, nie są łatwo dostępne. Bibliografie jego prac krytycznych, autorstwa Marii Alexandrowicz, znaleźć można w wydanej przez Towarzystwo Naukowe w Toruniu, zredagowanej przez Henryka Elzenberga książce Tadeusz Makowiecki (1956).

Publikujemy tu wybrane inedita krytyczne badacza. Ich teksty oparliśmy na maszynopisach znajdujących się w Archiwum PAN w Warszawie. Szkic o Wietrze od morza Żeromskiego (nie opatrzony tytułem) po wojnie został ogłoszony tylko szczątkowo („Jantar” 1946, z. 2) - być może ze względów cenzuralnych. Tekst o Oziminie pozbawiony jest jakiejkolwiek daty. Szkic o karierze kapitana Rykowa w literaturze polskiej przedstawił Makowiecki na ostatnim posiedzeniu KLiN-u, 20 grudnia 1945. Nie wiadomo, kiedy i gdzie nadany został radiowy - popularny, a przecież ze względu na kompetencje autora wart uwagi - odczyt o Wyspiańskim, napisany w 1947 roku.

W układzie publikowanych tu tekstów pominięto niepewną - i mało istotną - chronologię. Wybrano porządek dyktowany ich wartością: dwa skromne szkice o naturze przede wszystkim informacyjnej zostały umieszczone pomiędzy świetnymi studiami, w których talent krytyczny Makowieckiego zabłysnął w pełni.

Pisownię oraz interpunkcję dostosowano do obecnych zasad.

Nie poprawiano cytatów, które Makowiecki podawał niezbyt dokładnie, na ogół ich nie lokalizując. Stanowiące wyjątek trzy przypisy w jednym ze szkiców dostosowano do konwencji wydawniczej „Pamiętnika Literackiego", uzupełniając w nawiasach kwadratowych brakujące elementy. Nawiasy kątowe sygnalizują miejsca, w których osoba przepisująca tekst z manuskryptu nie zdołała odczytać wyrazu, zdania lub większego fragmentu.

\section{KARIERA KAPITANA RYKOWA W LITERATURZE POLSKIEJ}

Nikita Nikitycz Ryków urodził się w roku... mniejsza o to, którym, dość że w r. 1811 był kaptanem i dowódcą roty, czyli kompanii, w pięćdziesiątym pułku jegrów pierwszej dywizji dziewiątego korpusu wchodzącego w skład drugiej armii. Armia ta kwaterowała na Litwie.

Już ta jego ranga była niemała, nie byle jaka. Niepomiernie jednak wyższe były jego odznaczenia wojskowe. „Miał osiem medalów i trzy krzyże; medale za Oczaków, za Izmaiłów, za bitwę pod Nowi i pod Prejsiż Iłów” (zapewne Preussisch Eylau), Austerlitz i pod Zurich, ,a także i za męstwo szpadę, także od feldmarszałka trzy zadowolenia, dwie pochwały cesarskie i cztery wspomnienia, wszystko na piśmie". Walczył ponadto w kampanii polskiej od Racławic po Maciejowice; w pierwszej bitwie kosynierzy wysiekli mu pluton kosami - był wtedy jeszcze sierżantem; w drugiej atakował na bagnety. 
Jak widzimy, przebieg służby typowo frontowy, liniowy, awans w ciąu lat z sierżanta na kapitana w kampaniach: tureckiej, francuskiej, pruskiej, polskiej; awans jak na osiem medali bojowych i szesnaście lat walk może nawet nie tak olśniewający, jak ten, który spotkał go niebawem, gdy z dziewiątego korpusu drugiej armii przeszedł do dziewiątej księgi Pana Tadeusza, robiąc niebywała karierę literacką, zajmując - jako cudzoziemiec - pokaźne wcale stanowisko w epopei narodowej.

Czemu zawdzięczał to przeniesienie ze służby wojskowej do służby literackiej?

Niewątpliwie najpierw swej dzielności. Świadczyły o niej nie tylko owe „osiem medalów”, trzy krzyże oraz dziesięć pochwał („wszystkie na piśmie”), ale i czyny wojskowe, dokonane nie na Bałkanach czy w Prusach, ale podczas akcji epopei. To on przecież, gdy major Płut lekkomyślnie rozpuścił swój batalion, pozwoliwszy na dodatek spić podwładnych beczką spirytusu - pierwszy zorganizował jaki taki opór, stworzył szyk bojowy, z którym potrafił przejść do ataku i zagrozić bezpośrednio dworowi Sędziego. On po rozbiciu tego ataku szybko opanował sytuację, sformowawszy trójkąt, i rozbił atak konnego oddziału Hrabiego. On wreszcie - w zastępstwie tchórzliwego zwierzchnika - przyjął z Hrabią pojedynek i bił się z nim według wszelkich kanonów.

Jakież były jeszcze dalsze jego tytuły do uzyskania przydziału w epopei. Był lubiany lub, ściślej, tolerowany przez ziemiaństwo, „u których na kwaterze stawał od lat wielu”; mówiono o nim „człek poczciwy”, „stary żołnierz”, ,jakby przyjaciel”. Cóż poza tym? „Jadał smaczno, mało wdawał się w rozmowę”, „milczkiem kielichy wychylał”, później trąbił na fajce, niekiedy „na bałałajce grywał”, ot, mruk raczej, ale w tym mruków towarzystwie czasem mówił: ,ja was państwo Lachy lubię, że wy ludzie weseli, dobrzy do wypitki, a także ludzie śmiali, dobrzy do wybitki”, „Z wami ja sobie zjem, popiję, pohulam, pogawędzę i tak sobie żyję”.

A to dobre poczucie w polskim towarzystwie ocenić umiał nie tylko słowem, ale i czynem, gdy ratować chciał swych gospodarzy z kwater i ich $\langle\ldots\rangle$ z przykrej i, co tu mówić, gardłowej sprawy, gdy gardłował za nimi wobec majora Płuta, gdy potem ugodził się $z$ nimi honorowo. Ten ostatni wyraz należałoby podkreślić podwójną kreska, bo nie tylko $z$ honorem, ale i z brakiem honoru się łączy. Dobitnie i z naciskiem mówił Ryków: „państwo Lachy, już jest tu gadka między wami, że każdy Moskal - złodziej”. Temu powszechnemu sądowi przeciwstawił siebie - skromny żołd kapitański starczał mu na „ponczyk i lulkę tabaki”, o więcej nie dbał. Opinię zresztą powszechna o łapownictwie swoich kolegów potwierdził w słowach o Płucie, gdy radzi mu „gębę zatkać bankowym papierem (...)”.

Uczciwością więc i poczciwością wyróżniał się ze swego jegierskiego otoczenia. Poza tym stary żołnierz, mruk i prostak, jeśli się rozochocił i rozgawędził, to zamiast układać zdania chętniej sypał przysłowiami i powiedzonkami wojskowymi, ot, swoisty Pan Jowialski à la Strogonoff.

I to chyba wszystko, co możemy ważniejszego powiedzieć o kapitanie Rykowie - przynajmniej z czasów ostatniego zajazdu na Litwie (pewne kwestie zachowuję sobie na później).

Ale na tym bynajmniej nie skończyła się kariera kapitana Nikity syna Nikity, i to we wszystkich możliwych kierunkach - kariera doprawdy wspaniała, jak by mu powiedział któryś z kolegów z jegierskiego pułku: „błyszcząca”. 
Pomińmy na razie kresy północne, litewskie, zapomnijmy imię i nazwisko kapitana, zwróćmy się ku kresom południowym, ukraińskim, podolskim i pamiętając tylko szarżę (no i awans), zacznijmy szukać nie kapitana już, ale majora.

Znajdziemy go szybko w pięknym dworze hrabiostwa Respektów w Fantazym. Ukrył go wprawdzie Słowacki pod nazwiskiem zmienionym - Wołdemar syn Hawryły - ale już wkrótce poznali go tak przemienionego tacy bystrzy tropiciele wpływów i związków, jak Tretiak i Tarnowski. Jeden z nich pisał oględniej, że Major to „bliski krewny Rykowa”, drugi wręcz, że to Ryków „podniesiony do potęgi bohaterstwa”; zarzucał przy tym poecie niekonsekwencję, bo prototyp był przecież prostakiem, „żołnierzem z czasów Suworowa, a nie jednym z dekabrystów, którzy należeli do najuczeńszych, najbardziej ucywilizowanych ludzi swego czasu w Rosji”. W ten sposób w majorze Wołdemarze „pod osłonami (...) ukryte zostało litewskie "rykowstwo" "**.

Ostatni monografista Słowackiego potwierdził chytre domysły swych poprzedników: „A że - pisał - w fantazji jego (czyli Słowackiego) tak silnie odżył Pan Tadeusz, więc zrodziła się chęć, by wśród grupy polskiej umieścić Moskala, jak Mickiewicz Rykowa ulokował wśród towarzystwa soplicowskiego. Tylko Rykow był dla Słowackiego zbyt prosty, zbyt prozaiczny. Trzeba go było podnieść, upoetyzować. Dekabrystą więc (...) stał się"***. Krytyk dwukrotnie używa tu przysłówka „więc”, wskazującego na oczywistość lokowania Moskali w domu polskim. Mimo tej oczywistości, mimo trzech znakomitych autorytetów, mimo wreszcie - co dziwniejsze - że słuszne wydają mi się ich poglądy, spróbuję sięgnąc po więcej argumentów, licząc, że przy bliższym poznaniu zrozumiemy pełniej tajemnicę „błyszczącej” kariery kapitana Rykowa.

Istotnie, żył wtedy Słowacki w kręgu Pana Tadeusza. W Fantazym Kleiner poza osobą Majora widzi też odbicie pewne Telimeny w postaci Idalii oraz spowiedzi Jacka-Robaka w spowiedzi Majora.

Wydaje się, że listę zbliżeń i pokrewieństw obu utworów można by znacznie powiększyć. $\mathrm{W}$ ogólności zbyt wiele $\mathrm{w}$ tym dramacie widzi się autobiografizmu, cieniów Krasińskiego, Bobrowej i jej rodziny (Zosi, a nawet męża, p. Bobra), za mało pamięta się, że poeta mieszać zwykł na swej palecie bogactwo różnych farb, że były w tym dramacie i rysy własne poety, i Delfiny Potockiej, może i Moszczeńskich, ale nade wszystko czyste farby brane $\mathrm{z}$ różnych palet, nawet własnych (warto tu porównać Idalię $\mathrm{z}$ Goplana).

Zaglądając do kart Pana Tadeusza można by znacznie większe jeszcze zresztą niż do Idalii znaleźć podobieństwo Telimeny do hrabiny Respektowej, a w postaci hrabiego Fantazego można by poza niewątpliwymi rysami hrabiego Zygmunta dopatrzyć się także rysów Hrabiego przez duże „H”, krewnego Horeszkom, „chociaż po kądzieli”. Respekt ma pewne rysy Sędziego (serdeczność, zapobiegliwość, układanie małżeństw; motyw małżeństwa właścicieli najbliższych sobie majątków - też podobny). Marginesowo można by wspomnieć, że jak tam Hra-

* S. Ta r n ow s k i, [Studia do historii literatury polskiej. Wiek XIX.] Rozprawy i sprawozdania. T. 1. [Kraków 1895, s.] 165.

** J. Tretia k, Juliusz Stowacki. T. 1. Kraków 1904, s. 358 [właśc. 370, 368].

*** J. Kle in e r, Juliusz Stowacki. T. 3. Warszawa 1923, s. 272. 
bia pojedynkuje się $z$ Rykowem-kapitanem, tu hrabia Fantazy ma pojedynek z Majorem. Dość jest więc względów ubocznych świadczących o możliwości przejścia kapitana Rykowa ze służby w epopei jednego wieszcza do dramatu drugiego wieszcza.

Sięgnijmy teraz po charakterystykę Majora:

Był odważny... „kiedyś na tureckiej wojnie z Persami się bił... w kwarantannach służył i śmierci palcem dotykał - nie blady!"

Był prostakiem - cały pomysł porwania i sposoby argumentowania przy tym świadczą o tym bez żadnych wątpliwości - ten prymitywizm wybija się na plan pierwszy.

Miał sympatyczny stosunek do Polaków, „serdecznie serca wasze umiłował” wzajemnie cieszył się serdeczną ich życzliwością.

Mruk i odludek, „w domeczku małym i w sadzie cały dzień trubku kurzył”.

Łapówki - w odróżnieniu od Rykowa - brał, ale to było dawno bardzo; ten rys, przy jego skromnym życiu „w domeczku małym” i przy hojności przedśmiertnej, schodzi w cien, „niegdyś w kwarantannach srogi dla kupców - nu tak, przyjął podwieczorek", w tło jakby konieczne przy obronie rosyjskiego oficera.

Na tym kończą się zbieżności. Dekabrysta, przyjaciel Rumina, Pestela, Apostoła, brał udział w spisku na cara, ale zabobonny lęk uczuł przed jego obliczem, „taj paszoł w durnie"; zesłaniec na Sybirze, potrafił być wiernym przyjacielem i życie swe poświęcić dla tej przyjaźni (do Jana) i dla serdecznej znajomości z rodziną Respektów (a zwłaszcza z ich córkami, dla których życzliwy jest szczególnie, niemal po ojcowsku).

Ale ten major - i ten szczegół podkreślę teraz, acz jeszcze ogólnikowo - spełnia tę samą - lub ściślej - podobną rolę kompozycyjną co Rosjanie w Panu Tadeuszu. Tam oddział rosyjski przychodzi „na pomoc” Sędziemu i jego stronnikom, ale ten przywołany sojusznik staje się nagle koszmarnym ciężarem i Sędzia, i Telimena, i Zosia błagają, by przestał się nimi opiekować - tu grupka Rosjan z Majorem chce pomóc Respektom w ich kłopotach, ale jak pomoże, to i Respekt, i żona, i obie córki włosy sobie $z$ głowy wyrywają, aż gościnny gospodarz nie może nie zawołać: „mówię tobie szczerze, to niech cię wszyscy diabli, mój Majorze”. Ten rys „niedźwiedziej przysługi” cechuje grupę rosyjską w obu utworach. Do tych spraw jeszcze zresztą wrócę.

Tu słuszną uwagę zrobił Tretiak, że jak na jednego z dekabrystów, „którzy należeli do najuczeńszych, najbardziej ucywilizowanych ludzi swego czasu w Rosji”, Major jest zbyt wielkim, zbyt nieokrzesanym prostakiem - ot, jak Ryków, „żołnierzem z czasów Suworowa”, że, słowem, ,(...) wyłazi wszystkimi szwami prototyp postaci, "grube rykowstwo". Ale to jeszcze nie wszystko.

Jeszcze jedno należy rozważyć w związku $\mathrm{z}$ postacią Majora - jego znaczenie dla ideowej strony sztuki. Kołaczkowski pisze: „w całej naiwności, barbarzyństwie i pospolitości grzechów ukazał Słowacki Majora, by człowiek tylko, człowiek ułomny i grzeszny, wzniósł się w prostym odruchu serca nad poetyczne dusze" - i dodaje - „oczywiście prostota przeciwstawiona jest jako wartość - sztuczności, koturnom, pozie, komedianctwu i pustemu deklamatorstwu”. Major nie sam osądza - bo na to jest zbyt naiwny i prostolinijny - ale przez kontrast $\mathrm{z}$ soba pozwala czytelnikom i widzom dramatu osądzić skomplikowaną pustkę, jaka panuje w światku 
ziemiańskim, zgrupowanym u hr. Respektów. To jest jego rola zasadnicza w dramacie. Pamiętajmy.

A teraz zamknijmy znów i tę z kolei książkę, gościnny dwór na Podolu, zapomnijmy o nazwisku majora Wołdemara, spróbujmy w innym otoczeniu, w innym miejscu poszukać dalszego etapu jego kariery literackiej; pamiętajmy jednak o awansie (oficerowie lubią awanse), że należy szukać teraz już - pułkownika.

I znów bez większego trudu znajdziemy Pułkownika, tym razem w centrum Polski, w Warszawie na wielkim przyjęciu u baronostwa Nieman - w Oziminie. Jakby nie mogąc się zdecydować na nazwisko Nikita Ryków czy Waldemar Gawryłowicz - Berent nie dodał ani imienia, ani nazwiska do „szarży”: Pułkownik, i kropka.

Pułkownik ten znajduje się w towarzystwie wyłącznie polskim; wyłącznie - jak kapitan Nikita, gdy w I księdze zasiadał przy stole biesiadnym w Soplicowie, jak major Wołdemar później w pałacu podolskim.

Przyjrzyjmy mu się nieco:

Pułkownik jest nie tylko dobrym żołnierzem. Ciepło wspomina swą młodość wojskową w r. 1863, rozpręża się w szczerym męskim porywie ku nowej wojnie; nawet zewnętrzny styl jego ruchów i poczynań, „krzepkość tej poważnej postaci, ukłon chrzęstny, krótki pobrzęk szabli narzucały jakby rytmy szparkie” (63).

Jest to dalej człowiek prosty, „dobrodusznie zażyły, poczciwie niedbały, nie oszczędzający sobie po wschodniemu i cichej złośliwości w akcentowaniu swej prostoty wobec n a d mi a r u cudzej gentilezzy" (60). (Ten rys złośliwej świadomości swej prostoty jest dodatkiem nieznanym jego poprzednikom.) „Zło u nich - u Polaków, powiada - jest za mądre, za chytro-kryte jak na nas. My przy nich durne jak chłopy" (77).

Ta „dobroduszna złośliwość” zamienia się jednak w szczery wybuch życzliwości, gdy spotka dawnych znajomych; budzi się wtedy „ta powaga prostoty, $z$ jaką tamtejsi ludzie starsi umieją się jeszcze zbliżać do kobiet i dzieci" (62). Radość ze spotkania z Niną, 〈...〉, ojcowska opiekuńczość nad jej żywiołowością, przypomina stosunek Majora do Stelli i Diany.

Przez Polaków jest Pułkownik tolerowany (,lubiany” byłoby powiedziane o wiele za wiele, czasy od połowy wieku XIX się zmieniły), a sam ich lubi, mimo wszystko, mimo niechęć i pogardę, coś go do nich ciagnie. „Czego ty Papa do nich leziesz” - wyrzuca mu syn. Może go pociaga skomplikowanie duchowe, może „starszość” cywilizacyjna, dość, że bywa i patrzy.

A nie tylko patrzy, ale i sądzi.

„Z tymi ludźmi nigdy nie zażyjesz. Coraz to grzeczniej między nimi i coraz bardziej ślisko. Każdy (...) uprzejmości z oczu i ust sączy, byleś się o niego nie otarł odrębnościa jaką, byle życie samo przebiegało mu się gładko po duszy. Żadna ręka tu drugiej mocno nie chwyta, żadna myśl cudzą się dolą nie zatroska. I wszyscy, rzekłbyś, jednacy" (60).

„Że też u nich każde słowo musi być ckliwe i fałszywe - (...) z flaszeczki” (78). „I na co to wszystko? po co tak przechytry ich krok tu każdy? Jakie sprawy tu zawiłe, jakie losy tu się ważą?” (80) 〈cytat nieczytelny〉 (111). Dwa jeszcze fragmenty trzeba odrębnie przytoczyć. Pułkownik spotyka Ninę w tańcu: „Nie wysiepiesz ty w tym ochoty swojej - mruczał - nie wytańczysz jej całej (...). Czemu ty nie ruska!" (81). A po raz wtóry Pułkownik wraca do sali biesiadnej z pismem ze sztabu: „otwie- 
rał już był usta, lecz słowo polskie nie chciało się w tej chwili przecisnąc przez nie: za eleganckie, za wykrętne, za śliczne wydało mu się jak na okazję. Nagle podrzuciło mu się ramię i przybił jak kułakiem twardym słowem rosyjskim - wajna" (118).

Jak widzimy, stosunkowo niewiele pozostało w Pułkowniku cech dawnych, kapitańskich - ot, dzielność żołnierska, prostolinijność, szukanie polskiego towarzystwa; więcej znacznie wspomnień Majora, bo i poprzednie rysy można by wymienić, i dworną serdeczność wobec młodych i kobiet, i nade wszystko - słowa Pułkownika. Co tam - u Słowackiego - o Polakach nie zostało wypowiedziane wręcz, a tylko postawione i pozostawione czytelnikom czy widzom do sformułowania, do ujęcia przez porównanie grupy polskiej z Majorem - to tu u Berenta dopowiada Pułkownik własnymi, dobitnymi słowami.

Ta szorstkość w postawieniu spraw wywołała reakcję.

„Któż zacz jest ten człowiek aby go przeciwstawiać w sensie dodatnim społeczeństwu polskiemu?" - pytają krytycy.

A jeden odpowiada: „Typowym przedstawicielem dezorientacji i oślepienia. Tylko rozpaczliwa tęsknota za czymś nowym i innym, tylko obrzydzenie do "chorób cywilizacji» może pchnąć do zachwytów nad pułkownikami. Te same warunki i dyspozycje psychiczne wywołały wiek temu hasło powrotu do natury, kazały nie tylko Russowi ale i Chateaubriandowi i Wiktorowi Hugo tęsknić do różnych Irokezów, Cyganów itp." Pamiętając o Chateaubriandzie zapomniał krytyk o Słowackim.

A różnica pomiędzy bohaterami Słowackiego i Berenta była w gruncie taka, o jakiej wspomniał w rozmowie Wojciech Stanisławski (?) z Oziminy: „Gdy ojcowie współczuwać już zaczynają, synowie już lekceważą" (62).

〈Ze skreśleń wynika, że następny przykład, z Urody życia, został usunięty.〉

Materiał mniej więcej zgromadziliśmy. Pewnie, że nie jest on kompletny. Wiele sylwetek oficerów rosyjskich ukazuje się jako sylwetki przeważnie czarne wśród obrazów naszej literatury. Ale będą to albo chłodni, wrażliwi intelektualiści z końca XIX wieku, albo różne mętne profile, zbliżone do osławionych typów „czynownika” czy jeszcze bardziej może słynnego typu „żandarma”.

My tymczasem zajmowaliśmy się tylko stopniami kariery (czy raczej genealogicznym drzewem) kapitana Rykowa. Nagromadzony materiał powinien już wystarczyć do wyprowadzenia wniosków.

Jakich? Stwierdzenie, że postać majora Waldemara Gawryło powstała pod niejakim wpływem Rykowa, a znów Pułkownik Berenta ma różne rysy Majora z Fantazego - to jeszcze za mało. Ewangeliczny - w swej prostocie - tok zdań typu: Abraham zrodził Izaaka, Izaak zrodził Jakuba, nie może służyć za najwłaściwszy wzór dla krytyka czy historyka literatury. Owszem, można zanotować ów łańcuch w kalendarzyku wpływologicznym, ale poprzestając na tym - trzeba pójść dalej w innym kierunku.

W rysach nakreślonych przez siebie postaci próbowali wszyscy pisarze - na tle polskiego społeczeństwa - ująć odrębność Rosjanina, lub ściślej - oficera rosyjskiego - nie czynownika, żandarma, kupca czy chłopa - ale oficera. Widzieli w nim najpierw: sprawność i dzielność żołnierską, połączone $z$ odwagą i skłonnością do ryzyka, prostoduszność szczerą i życzliwą, ale nade wszystko - prymitywizm. W swych słowach, odruchach i czynach sa oni prostolinijni nieraz do granic prostactwa. Prostolinijność rozumowania i idącego zaraz za nim postępowania cechu- 
je ich wszystkich, niezależnie od poziomu -i rangi wojskowej czy duchowej. Dalszym rysem ich prymitywizmu - poza prostolinijną nieraz naiwnością - jest ich stosunek do życia.

Gdy pół roty ginie w awanturze soplicowskiej, Ryków pociesza się maksymą: „dziś żyjem, jutro gnijem”, Major Hawryło życiem swym szafuje jak karta - i to nie w chwili uniesienia; Pułkownik wybiera się na wojnę, ochoczo dla „〈... lekkomyślnej”. Ten prymitywizm i odrębność reakcji coraz drażnią polskie otoczenie, coraz doprowadzają do cięższych nieporozumień i konfliktów. 〈fragment tekstu nieczytelny $\rangle$. Te i inne podobne cechy charakteru ukazane sa jakby mimochodem w słowach i odruchach postaci drugo-, jeśli nie trzecioplanowych w wymienionych utworach.

Ale znów i ta sprawa nie wydaje się ważna dla historyka literatury; stoi na pograniczu socjologii, na marginesie właściwych badań, charakteryzuje tylko jeden z elementów treściowych dzieła.

Nasuwa się $z$ kolei dalsza kwestia. Wszystkie wymienione osoby oficerów odrzutowane zostały przez autorów $z$ wyraźną sympatią. Tymczasem jeśli nawet Mickiewicz miał „przyjaciół Moskali” (wśród elity - dodajmy), Słowacki i Berent należeli do zdecydowanych rusofobów: $\mathrm{z}$ niechęcią i odrazą odnosili się do wszystkiego, co moskiewskie i słowiańsko-wschodnie. A jednak... Albo więc ci przedstawiciele obcej armii, z którymi się stykali pisarze, byli tak ujmujący w swej bezpośredniości, że umieli zwalczyć na swoim odcinku niechęć zasadniczą do kultury i mentalności rosyjskiej - albo pisarze wielcy, w chwili tworzenia, zbyt byli ludzko życzliwi i imponująco bezstronni, by nawet drugorzędne postaci ze swoich utworów zabarwiać swoimi politycznymi lub kulturalnymi uprzedzeniami. Przynosi to odmienny, ważny rys ich wielkiej twórczości. Starali się sięgnąc do ludzkich prawd, do założeń duchowych swoich bohaterów. Ale znów to raczej sprawa etyki pisarskiej, psychologii twórcy: tylko na pograniczu, na ukrainach, na dzikich polach literacko-naukowych możemy je rozpatrywać.

Ale przechodzac tak od problematu po problemat zaczynamy czuć pewien prą... Jak w dziecinnej zabawie w chowanego: zimno... ciepło... ciepło. Przechodzę do punktu gorącego.

Oto nieco ironizująca życzliwość wobec przedstawicieli świata rosyjskiego łączy się z co najmniej równie złośliwą życzliwościa - jeśli nie wręcz z napastliwościa wobec świata polskiego. A nawet, w pierwszym wypadku, równie złośliwa życzliwość inny daje wynik, inaczej dźwięczy wobec wroga, inaczej, ostrzej, wobec rodaka.

W Panu Tadeuszu mamy (zwłaszcza w księgach V-VIII) zapadły prowincjonalny krag życia, prawdziwie „zaścianek”, który obraca się około drobnych zadrażnień, małych ambicyjek, pustych ceremonii, ograniczonych interesów. Ten światek zaczyna wirować szybciej w okresie zajazdu - ale wciąż po tej samej orbicie. I w to krążenie wchodzi czynnik obcy, sztywny i prostolinijny. Właściwie jest on tylko reakcją wobec pewnych sił, chcących „siłą” przeforsować swoje prawa czy raczej uroszczenia; wprowadza sztywne konsekwencje wobec założeń tkwiących w samym ruchu, w samym krążeniu; powoduje zupełną przemianę nie tylko wewnątrz stosunków między dotychczasowymi nieprzyjaciółmi sąsiedzkimi, ale i zupełna przemianę wartości każdego z nich. Mówiąc dzisiejszo - à la mode - następuje rozbicie atomu soplicowsko-dobrzyńskiego. Nagle nikną drobne, błahe sprawy, nagle jawią się z ukrycia mocne rysy serio - wszystko zaczyna wirować na innej płaszczyźnie, 
około innych ośrodków. Gdyby nie to zetknięcie obcej, brutalnej prostolinijności - zajazd zakończyłby się pewnie jakimś „kochajmy się. Mniejsza z tym. Mówimy o gdyby... Dość, że ostatnie dwie ksiegi epopei, gdzie z armią napoleońska, w blasku orłów, w powiewie historii przyjeżdżają na Litwę Tadeusz, Sak, Konewka, Hrabia, a witaja ich tak blisko im stojący soplicowi goście - nie mógłby mieć miejsca. Ot, gapiliby się przed gankami swych chat czy dworków na przeciagającą epopeję - jako widzowie mali, zaściankowi; gdy tam przyjeżdżaja jako uczestnicy, gdy tam witają - jak równi. W IX księdze obiit niejeden Gustavus, natus est niejeden Conradus. Wagę tej księgi i rolę pojawiającego się czynnika obcego - Rosjan - należy, zdaje się, znacznie mocniej podkreślić. 〈Zdanie nieczytelne.)

W Fantazym ,wielki świat” jest wielki tylko w cudzysłowie; krąży on naokoło błahych plotek, kaprysów zrodzonych z nudy, bardzo przyziemnych interesów, małych uczuć, pustego aktorstwa. W to krążenie wchodzi czynnik obcy, sztywny w swej prostolinijności - Major, który wyprowadza sztywne konsekwencje z założeń tkwiących w tym światku, który chce przecież usunąc przeszkody dla projektowanego mariażu $\langle\ldots\rangle$. I ten właśnie czynnik powoduje rozbicie siatki Respektowo-Dafnicko-Rzecznickiej. Dawni sprzymierzeńcy czy przeciwnicy zaczynają działać wspólnie, inne sprawy stają się ważne, inne siły - dotąd ukryte w duszach bohaterów - wychodzą na jaw - mocno serio. Elementu dziejowo-epickiego w Fantazym nie ma, cały on jest skupiony koło przemiany duchowej. Za to również element prostolinijności zostaje uwikłany w skomplikowany systemat obcego sobie świata, i również ginie. Tylko w Panu Tadeuszu przemianę sprowadza jednoczesne niemal wmieszanie się czynników obcych - Rosjan, i zaraz po tym następująca śmierć ks. Robaka - tu, w Fantazym, kolejność obu tych elementów opiera się o jedna postać. Ale znamienne - już Kleiner przyznał, że w spowiedzi przedśmiertnej Majora wiele jest cech wspólnych ze spowiedzią Robaka; można by te analogie i w tym kierunku znacznie poszerzyć: zbliża ich bujna przeszłość, za którą czują wyrzuty, zbliża opiekowanie się Janem, niby przybranym synem - jak tam Tadeuszem, zbliża chęć wyswatania umiłowanego chłopca $\mathrm{z}$ wybraną przez siebie dziewczyna (jak charakterystycznie np. mówi Major: „Dziwoczka, siuda, nu, tak ty z różami na ustach... stań tu... ot, przy tym hułanie"). Zbliża ponadto owo spełnianie analogicznych funkcji kompozycyjnych w przełamywaniu się akcji obu utworów. Major to nie tylko ów kapitan upoetyzowany, jak chce Kleiner, ale i bernardyn.

Fantazy znacznie bliżej powstawał w kręgu Pana Tadeusza, niż się dotąd sądziło.

Świat Oziminy również z pozoru tylko jest „wielki”. Krąży on, a ściślej, obraca się dookoła bardzo mieszczańskich interesów, bardzo materialnych radości, bardzo gnuśnych upodobań; wiele tam bezwładu i powierzchownej, naskórkowej nerwowości... W ten obrót życia mieszczański, syty, przywykły do tapicerszczyzny wygodnej - wchodzi człowiek obcy, sztywny, prostolinijny; nie powoduje rozbicia tego światka bezpośrednio, raczej bowiem rezonuje, niż działa. Za to szybko włącza się element epicko-wojenny - Pułkownik jest tylko jakby medium idącej grozy i wielkości historycznej (którego brakowało u Słowackiego) - i gdy zaczyna oddziaływać, rozbija światek zgromadzony u baronostwa Nieman. Tylko że tu nie przekształcają się ludzie - brak tego katartycznego momentu jak w obu utworach poprzednich, ale są roztrąceni, zmiażdżeni psychicznie (jak Bolesław somnambuliczni) „(...) jak 
spod rozjeżdżonego kołami dziejów śniegu, wdeptanego w błoto, wynurza się ozimina - garstka ludzi idących (...)”. I znów zaznaczyć można mimochodem, że ta strona obca, która jest sprawca rozbicia salonu Niemanów - niesiona jest ku katastrofom wojny.

Konkluzja

We wszystkich utworach jest coś, co ośmieliłbym się nazwać motywem chochołowego tańca. Jest to uparte krążenie w kółko po małych orbitach, 〈...〉, krążenie nie prowadzące donikąd - niby powolne, mętne wiry, które powstają w rzekach zamkniętych stawidłami. $\mathrm{W}\langle\ldots\rangle$ niewoli, w zatrzymaniu życia narodu powstawały na przestrzeni różnych lat, różnych utworów, różnych środowisk owe wiry martwe. Zaściankowa szlachta z zapadłej prowincji litewskiej, podróżująca po świecie arystokracja podolska, zamożne mieszczaństwo warszawskie czy inteligencki świat Krakowa grają podobną melodię. Gdyby poszukać, byłoby tego motywu o wiele, wiele więcej.

Mógłby ktoś postawić mi zarzut kompleksu Wyspiańskiego. Przyznaję się, ale... Zwłaszcza chochołowość Pana Tadeusza mogłaby oburzać. Ale - 1) chochołowość ta odnosi się nie do całości, ale pewnych tylko ksiag epopei, 2) że jest - stwierdzał to Mickiewicz w słowach Maćka („głupi, głupi”), 3) że jest - stwierdził Słowacki w Fantazym (wiemy bowiem z dziesiątków badań, że Słowacki podejmował motywy muśnięte przez Mickiewicza i wygrywał je pełniej). Wiemy skądinąd, i to starałem się podkreślić, że cały Fantazy mieści się w tym motywie Pana Tadeusza. A skoro tak jest, nie sposób pomyśleć, aby centralne zagadnienie Fantazego - ukazanie pustki wewnętrznej - jakimś choćby muśnięciem nie dźwięczało na pewnych kartach Pana Tadeusza.

Wiem, że mógłby ktoś postawić drugi zarzut: kompleks Norwida. Trudno, nie będę się wypierał. Wydaje mi się, że to, co musnął ledwie Mickiewicz, to wyśpiewał Słowacki, to wykrzyczał Berent. Wreszcie 4) wzgląd obronnej natury. Musiało się różnić w rytmie, w jakości i wielkości owo ślepe krążenie - na początku wieku niewoli (gdzie ledwie się mogło zaznaczać) i po stu latach, w straszliwym ciśnieniu atmosfer niewyżytego życia nad chatą bronowicką i nad salonem warszawskim. Nie dziw, że tam może łatwiej ujść uwagi, ale przebłyski tego sa.

Mógłby mnie spotkać jeszcze trzeci zarzut, że w ogóle ten problemat należy do dziedziny historiozofii czy socjologii, ale nie do integralnych badań literatury. Tu odpowiem nieskromnie - owszem, należy. Starałem się wielokrotnie (używając nawet identycznych zwrotów) podkreślać pewne podobieństwo w strukturze utworu, w kompozycji akcji, w motywacji momentów przełomowych, w charakterystyce czynników działających. Wykazywałem, jak pewne rodzime kręcenie się w kółko musiało spotkać się z sztywna, obca prostolinijnością, by zmienić orbitę; jak ów czynnik obcy spełnił jakby role katalizatora, powodując szybsze krystalizowanie się przesyconych pewnymi wartościami atmosfer. Wszystko po to, aby obecnie móc stwierdzić, że treść łączy się tu ściśle $\mathrm{z}$ formą. A ponieważ treść czy forma utworu to toż samo, tylko ujęte $\mathrm{z}$ różnych punktów widzenia - przeto $\mathrm{w}$ tym wypadku, zajmując się treściowymi składnikami - nie zajmuję się treścią heterogeniczną, ale integralną, tą, która kształtowała formę dzieła. A zatem jako badacz literatury mam prawo się nią zajmować. Ale nie to jest najważniejsze, lecz to, że połączenie strony treściowej i formalno-konstrukcyjnej świadczy, że rozpatrywane tu zagadnienie roli 
rosyjskiego oficera w kilku utworach literatury polskiej, mimo pozornie zupełnej marginesowości, otwiera wgląd w sprawy istotne, ważne dla tych dzieł. Te drobne często role nie są epizodyczne. A więc warto może było przyjrzeć im się nieco bliżej.

Oto wszystko.

\section{ODCZYT O WYSPIAŃSKIM (1947)}

Czterdzieści lat upłynęło od śmierci Wyspiańskiego. Przyniosły one wiele studiów i rozpraw, oświetliły niejedną mroczną stronę jego dramatów. Wydano krytycznie całość jego dzieł w ośmiu grubych tomach. Wiele $z$ tych dzieł dotarło pod strzechy, a w każdym razie do uczniowskich tornistrów - choć gdy się pojawiały, były okrzyczane za niepojęte. $\mathrm{W}$ bibliotekach czy w teatrach, a wreszcie w muzeach (nie wolno przecież zapominać o jego obrazach) utwory Wyspiańskiego należą do podstawowego składu.

A przecież gdy lat temu czterdzieści w Krakowie tłumy z całej Polski niosły ubogą trumnę na Skałkę, rozumiejąc, że tracą jednego z największych - nie rozumiały ani wielkości, ani różnorodności jego puścizny.

I my dziś, po tylu latach, również nie doceniamy całej wielkości tego prawdziwego fenomenu, jakiemu na imię: Wyspiański.

Przyzwyczailiśmy się do jednych jego dzieł, zapomnieliśmy o innych. Jako człowiek odszedł na dystans całego pokolenia, jako twórca odsunął się poza lata dwóch wojen. A przecież - gdy się zastanowić - uderza wciąż z tą samą niezwykłością i potega swego dzieła - teraz jak przed latami... Uderza nie tylko dlatego, że był jednocześnie poeta, malarzem, grafikiem. Bywali tacy renesansowi bujni twórcy. Ale dlatego, że był twórczy, przełomowy - we wszystkich tych dziedzinach, których się dotknął.

Zrewolucjonizował teatr polski, dekoracje i inscenizacje, zreformował graficzny układ książki, pchnął na nowe drogi sztukę zdobniczą, odrodził monumentalną sztukę religijną wielkimi witrażami i polichromiami, otworzył oczy malarzy na świat dziecka, w pastelowych, zwiewnych krajobrazach był nie mniej oryginalny jak w surowej liryce. Wszystkie te przełomowe dzieła były przecież tylko marginesem jego twórczości właściwej, twórczości dramaturga. W tej twórczości równie wielki i rewolucyjny był, gdy dotknął życia współczesnego, jak w Weselu czy Sędziach, czy gdy brał temat z przeszłości niedawnej, jak w Nocy listopadowej czy Warszawiance, bądź pradawnej, jak w Bolesławie Śmiałym czy Skatce, bądź wreszcie legendarnej, antycznej, jak w Achilleis czy Powrocie Odysa.

Co więcej, rozbieżne te dzieła łączył nie tylko swoją osobą - równoległością jednoczesnego tworzenia, ale głębiej i organiczniej. Współcześnie kreślił rapsody o Kazimierzu Wielkim i świętym Stanisławie, a zarazem zjawy tych właśnie postaci rzucał na olbrzymie kartony witrażów.

Do dramatu o Bolesławie Śmiałym i do Legendy szkicował lalki, kostiumy, dekoracje. Ukazując dramat na scenie, chciał, aby jego wizja sceniczna do najdrobniejszego szczegółu - do kształtu kominka, do rysunku na tarczy - harmonizowała $z$ treścią, by nie łatać obrazu teatralnego wypożyczaniem przypadkowych, ba- 
nalnych rekwizytów-szablonów. Dbał o jedność organiczną słowa-gestu-ubiorudekoracji, ba, także i oprawy muzycznej. Ukazując tenże dramat w druku, całe dni przesiadywał w drukarni, kreślił ilustracje, projektował przerywniki, wybierał rodzaje czcionek, komponował układ każdej strony. I tu też twór ducha ludzkiego dzieło natchnienia i pracy - miał objawiać się nie w byle jakim gazetowym składzie, ale zjednoczony $\mathrm{z}$ treścią, podkreślając graficznymi środkami powagę czy piękno całości.

Gdy pamiętamy i ogarniamy wielość i różnorodność dziedzin twórczo przeoranych przez artystę, zdumiewać się musimy bogactwem i wielkością jego talentu powiedzmy szczerze, nie wstydząc się wielkich słów - jego geniuszu. Ale gdy uprzytomnimy sobie ową ambicje jednolitości świata tworzonego przez artystę, musimy zauważyć, jak wyrasta on $\mathrm{z}$ ram XIX wieku, jak otwiera nam wiek XX.

Bowiem stulecie minione było pod koniec epoką liberalnej bezstylowości, eklektycznego mieszczaństwa. Tak jest w stroju kobiecym tych lat schyłkowych - bluzki o barokowych bufiastych rękawach spinano klasyczną rzymską kameą, a przepasywano paskiem $z$ klamrą skopiowaną koniecznie $z$ gotyckiej bramy. Podobnie było w architekturze, w sztuce wnętrz, w piśmiennictwie, w życiu, wszędzie.

U nas w Polsce, po dłuższej przerwie - od zapoznanego Norwida - pierwszy Wyspiański w takiej skali i z takim impetem przeprowadził zasadę, że jeśli epoka, życie, sztuka, dzieło mają być wielkie i prawdziwe, muszą być organicznie jednolite: od zewnętrznego drobiazgu po najwyższe czy najgłębsze osiagnnięcia wewnętrzne.

Oczywiście, nie wszystkie osiągnięcia Wyspiańskiego mogły się wyłamać spod wpływu epoki, w której wyrastał. Linie jego prac dekoracyjnych nieraz były zbyt secesyjne, a z kolei tok słów - zbyt surowy. Ale sama zasada jednolitości i niezwykła szerokość skali jej wprowadzania w życie - pozostały trwała zdobyczą.

Ta zasada jednolitości twórczej przy skłonnościach do krańcowo różnych, często sprzecznych dziedzin czy wartości prowadziła do syntez bardzo śmiałych, czasem paradoksalnych - zawsze bardzo własnych.

Przecież ten dramaturg, którego dzieła znamionuje zwarty, surowy monumentalizm kompozycji czy charakterystyki postaci, jednocześnie, w tych samych utworach, dawał fragmenty pełne najtkliwszego liryzmu, wystarczy przypomnieć np. w Weselu przekomarzanie się dziewcząt czy opowiadanie snu Panny Młodej, w Wyzwoleniu np. kolędę przy kołysce.

Przecież ten poeta-symbolista, wprowadzający na scenę zjawy duchów, ożywione posagi czy gobeliny, uznany za jednego z trudniejszych twórców Młodej Polski, pisał swe dzieła językiem niezmiernie prostym; jego niektóre zwroty weszły do mowy potocznej, nabrały cech niemal przysłów. $Z$ jednego Wesela wystarczy przytoczyć takie zdania, jak: „oni nie chcom chcieć”, „chłop potega jest i basta”, „Polska to wielka rzecz”, ,ale świętości nie szargać”, „miałeś, chamie, złoty róg”.

A który $z$ naszych, i nie tylko naszych, poetów $z$ owych lat - aż do ostatnich prawie czasów - umiał tak stopić w jedną całość klasyczną, legendarną przeszłość Grecji z codziennością współczesną, polską? Nie dziwimy się bardzo słysząc, że „Skamander połyska wiślaną świetląc się falą, a kruki zlatuja stadami od strony Sandomierza do jęczacej Kasandry.

Tak samo który z poetów potrafił tak prześwietlić ludzi bliskich, znajomych, 
kolegów, aby zmienili się w naszych oczach we wstrząsający sejm zbiorowego sumienia i w barwnym weselu ukazali niby przekrój narodu?

Kto miał tyle twórczej przekory, by $z$ wiechcia wymłóconej słomy, $\mathrm{z}$ przegniłego chochołowego snopu zrobić symbol dnia dzisiejszego?

Takich połączeń kontrastów, takiego powiązania przeciwieństw pełno jest w twórczości Wyspiańskiego-poety, ale także Wyspiańskiego-malarza. Wystarczy przypomnieć, że on, twórca olbrzymich kartonów witrażowych czy nie mniej wielkich szkiców do polichromii kościelnych, jest też autorem tylu delikatnych główek dziecięcych, tylu kwiatów, tylu pejzaży. Ale ta potęga jednoczenia w żywą całość rzeczy, kierunków, idei - sprzecznych lub choćby dalekich - sięgała w głąb do podstawowych elementów człowieka, narodu, kultury, życia w ogóle.

Ideałem dla poety nie było życie wegetacyjne, bierne, równe, jakaś pełnia dosytu, ale mocne, intensywne, rozpalone do czerwoności - rozpalone, a więc i spalające, życie płonące, a więc i niszczące samo siebie. Właśnie w najwyższych chwilach niemal już odmaterializowane i graniczące ze śmiercią. Ale śmierć to nie tylko nicość, ale martwota, zdrewnienie, chochołowa kołowacizna snu, ciężar bezmyślnego trwania. To uznawanie przez poetę pełni życia w okresach granicznych, wtedy gdy życie swymi ambicjami czy porywami sięga już poza życie, gdy gra o najwyższą stawkę, rouge albo noir, wieczność albo nicość - jest znamienne dla kontrastowych syntez Wyspiańskiego.

Podobnie jest $\mathrm{z}$ charakterem tragizmu. Bez wahań i złudzeń stwierdza poeta nieraz straszliwość istnienia, grozę klęsk i upadków. Ale... weźmy choćby najbardziej znane Wesele. Ludzie realni, wszyscy, dostają się w krąg kołowacizny Chochoła, przestają się liczyć jako ludzie; widma przeszłości pod przyłbicą czy maską ukazuja puste oczodoły. Słowem, teraźniejszość narodu opętana jest bezmyślnością codziennego dnia i zagubiona, a przeszłość martwa, widmowa. A jednak czy można porównać rozpacz ostatnich akordów tego dramatu $\mathrm{z}$ beznadziejną, gorzką rezygnacją innych książek, tzw. „schyłkowych”, choćby nastrojem Próchna Berenta. Mimo wszystko czujemy uśpione, ale tętniące podskórnie, bujne, elementarne życie. Czepiec, chłopi porywający za kosy, dziewczyny serdeczne, szczere, ludzie z miasta prawi, zatroskani o naród, naprawdę targający się wewnętrznie - są za mali, za słabi w obliczu Historii i jej wiecznych praw. Tak, ale krew w nich płynie, ale kościec mają zdrowy. Wystarczy wyzwolić ich z upiornego wpływu, by wyrośli wysoko. „Wyzwolenie” to nie tylko tytuł następnego dramatu Wyspiańskiego, ale wzorzec ideowy większości jego dzieł. Mimo tragizmu losu, we wszystkich bohaterach - Konradach, Bolesławach, Lelewelach, Hektorach czy Achillesach - czujemy siłę serca, szerokość piersi. Smutek i groza nieraz wieją z tych kart, ale nigdy beznadziejność i opuszczenie rąk. To połączenie tragicznego widzenia spraw świata i ludzi z ukrytą wiara - pomimo wszystko - w wartość życia i świata jest jakże typowo polską, arcypolską cechą utworów Wyspiańskiego.

I jeszcze jedno: gdy poeta swym syntezom zechce nadać kształt - jednoczy je w jednym symbolu. Takim typowym tworem Wyspiańskiego będzie Chrystus-Apollo w Akropolis. Nie Chrystus umęczony, bolesny, ukrzyżowany, ale zmartwychwstały, tryumfujaccy, w ciele promiennego greckiego boga na rydwanie słonecznym, gdy tratuje trumnę męczennika.

Ta moc wewnętrzna twórcy, która nieraz łączyła w jednej wizji syntetycznej, jak 
w wielkiej iskrze-błyskawicy, odległe moce: niebo i ziemię, wyżyny i niziny, życie i śmierć, wieczność i nicość - jest trzecią przyczyna, dla której warto jest czasem zamyślić się nad dziełem Stanisława Wyspiańskiego.

\section{[Bez tytułu - o Oziminie Wacława Berenta]}

Koniec wieku nie zawsze i nie wszędzie przypada na ostatni dzień ostatniego kalendarzowego roku stulecia. O innej porze wschodzi słońce w Moskwie - o innej w Paryżu. Dla Krakowa na przykład koniec wieku dziewiętnastego nastąił już na przełomie 1898 roku, gdy ukazało się „Życie”, gdy pojawiły się pierwsze tam utwory Przybyszewskiego, Wyspiańskiego, Micińskiego, Artura Górskiego, Kasprowicza, gdy „Sztuka” zorganizowała pierwsze wystawy (Stanisławski, Wyspiański, Jacek Malczewski, Mehoffer, Dunikowski), a teatr Pawlikowskiego uderzył pierwszymi dziełami Maeterlincka, Hauptmanna, d'Annunzia, Strindberga.

Gdy tak dla Krakowa godzina przemian uderzyła na kilka minut przed oficjalną dwunastą stulecia - dla Warszawy wybiła ona o parę kwadransów później i nie spiewnym hejnałem sztuki, ale zgrzytem ukazów mobilizacyjnych na wojnę japońską. Wybuch tej wojny i idący w ślad za nią wstrząs rewolucji 1905 roku otwierały wiek dwudziesty dla tej części Europy.

Ową właśnie historyczną noc między dwu stuleciami wybrał Berent za przedmiot swej powieści o Warszawie - Oziminy.

Bohaterów wiosennego przesilenia dnia $z$ noca $-\mathrm{w}$ przeddzień kiełkowania oziminy - skupił pisarz w dusznych, choć rozległych i bogatych, salonach baronostwa Niemann, na wielki raut-macabre mieszczańskiego fin de siècle’u.

Wygodne apartamenty uderzają głównie luksusem, luksusem pozaartystycznym, wywołującym specjalne apostrofy podziwu: „Cóż za ubikacja przedziwnie leniwego nabożeństwa... w tym spiętrzeniu dywanowych poduszek, taboretów, otoman, foteli, portier, kotar, kobierców i wezgłowi. Cóż za wykwint kaukaski, jakaż profuzja tapicerskiego geniuszu i perskiego natchnienia. Pozostawałoby już chyba tylko siąść na tym miękkim jak puch dywanie, wesprzeć głowę o taboret z poduszek, jeść sorbet i całować się słodkimi wargi".

Jedynym twardym sprzętem była stojąca w rogu czarna, hebanowa „wielka kukła Murzyna wyciagająca w swych łapach goryla tacę mosiężną, a w niej dzban kryształowy i lodową niby czarę. Bydlęca powagą nieodpartej jakby siły spoglądał jak sam czas wieczny, uczuć i namiętności rozkładowych świadek ponury, eunuch czarny z ślepiami jak przerażenie”.

A od tego saloniku pani niewiele różnił się gabinet pana, też oddzielony gęstymi portierami, też pełen głębokich foteli na równie puszystym dywanie, $z$ wielką otomaną i stołem okrytym tkaninami.

Nie dziw, że w tym świecie miękkości wszelakiej królować musiała - kobieta, a wśród kobiet - artystka.

Oto, jak pojawia się w przepełnionych gośćmi salonach znakomita śpiewaczka, wcielenie secesyjnego piękna, wspaniałości i sławy, powiew europejskiego zbytku i ostatniej... mody: 
„z szelestem ogromnym, jakby wleczonej za sobą gałęzi, ruszyła ode drzwi kobieta w srebrzystym białym stroju, cała od lśnień sukni i od brylantów na szyi jakby od rosy połyskliwa. Gestem ramienia chwytnym podejmowała tren sukni z tyłu, nieco poniżej stanu i, niby łabędź nastroszony, płynęła środkiem salonu, piersią i osadą bioder wypięta, kształtem litery S, łączącej sobą dwie wysady nazbyt sowite i soba jakby pyszne. Sukniami szumna, jakimś szalem czy puchowym "boa" w barokowe arabeski obramiona, zwracała ku ludziom bardzo biała twarz i zimny na niej uśmiech.

Z lic kobiet tryskała ciekawość na pierwszy widok śpiewaczki i jej sukni. Młodzież męska doświadczała tymczasem obiecującego dreszczyku poznania sławnej diwy. Gradem posypały się wersje, plotki i świństwa, szeptane na ucho".

A ona tymczasem „gestem królującej o oparcie rzucona, słała sobie podnóżek z spiętrzonych fałd trenu, bardziej jeszcze połyskliwych od sukni. Pochylona ku śpiewakowi skręcała się w sobie jak łodyga słonecznika, prężąc w tym przegięciu pychę i chłód nagiej piersi (...). Puchowe "boa" opadające $z$ ramion, ujmowało ją w białe ramy wirowych niespokojnych skrętów (...); i tym kształtem rysowała się cała: w kapryśnych esach, zygzakach, arabeskach, w barokowej fanfarze wielkostołecznego szychu".

Gdy tak wygląda władczyni i wzór niedościgły kobiecego wygodnego luksusu mieszkanki tego królestwa, panie zamożnej burżuazji stołecznej, zebrane w wielkim salonie, „dysza perfumami, promienieją w powietrzu fluidem cielesności białej” wytwarzają atmosferę cieplarni:

„gładkie ciała, małżonki nabywane po wszystkich targach: białogłowy cieliste o miękkim wejrzeniu i pulchnych policzkach. Twarze lekko obrzękłe, mleczne i przezrocze - przedziwne tło dla oczu ciemnych, w których tli się życie monotonne w lubieżności cichej. Ręce nie $z$ tych, które się do rozkazywania lub do marzycielskich bezczynności rodziły, raczej kuse, forsownie pielegnowane, przebiałe; dłonie, które chyba nigdy niczego nie dotykały i służyły na to tylko, żeby obładowane pierścionkami spoczywać przed oczyma ludzi na materiach sukien. Wszystkie te kobiety - siedzą nieco za szeroko na krzesłach - nie domykały się kolana nóg krótkich; sprawia to może pulchność osób lub, co prawdopodobniej, ta w bierności zawsze półsenna egzystencja hodowanych stworzeń, to ich nieustanne poczuwanie się do kobiecości - fizycznej”.

Nie oskarża ich jednak pisarz zbyt ostro, choć bezlitośnie zauważa wszystkie skrzywienia, śmiesznostki, przywary i winy. Jakżeż mogłoby być inaczej w małostkowej, przyziemnej, dusznej atmosferze mieszczańskiego bytowania, bez ambicji, bez walk, porywów, prac, ideałów?

"Gdy fala energii powszechnych opada, kobietom przede wszystkim leniwieja dusze i zatruwają się wyobraźnie próżne. Już nie ci, co "harmaty" zdobywali, królują w marzeniach, lecz egzystencje na atmosfere pokoju najczulej wrażliwe - artyści; dokonywuja im oni władz uczuciowych rozkładu lub też sami w tchnieniu dusz leniwych i wyobraźni zatrutych giną. Zepchnięte z koturnów romantycznych, rozsznurowane $z$ katolicko-salonowego gorsetu empirowej mody, równouprawnione przede wszystkim w pogoni za dosytem, te biedne niewiasty jałowieja po prostu z samego poczucia swojej dziś pospolitości”.

Jakżeż mogłyby innymi być wśród takich mężczyzn jak ów pan Horodyski, 
„grzyb wielkomiejski” z plemnikami cynizmu w głowie i w języku, jak ów fabrykant Szulc, któremu „między wyłogami fraka wyciskał się brzuch śmiejący niby dojrzały kasztan z pękniętej łupiny”, a który w kamizelce nosił brelok z „fotografią pornograficzna”, jak ów inny pan krążący po salonie wśród dam ,jak bąk wśród kwiatów...” - „wszczął rozmowę o sztuce i literaturze, by przemycać w niej rzeczy śliskie. Żuk kosmaty zawiesza się nad kielichem, sięga w najwstydliwsze dno kwiatu i ssie etery słów lubieżnych... flirtuje z panną". Nie ciekawsi bynajmniej są niedouczeni oświatowcy, suchotnicze indywidua, które po pracy biurowej tłumaczą nocami trzeciorzędną obcą literaturę, popularne encyklopedie i studia, albo owe "gaduły ciepło-serdeczne" z nędznych stancji studenckich, albo dziennikarze zabłąkani wśród okragłych papierowych frazesów, nie bardziej ciekawy jest ksiądz w jedwabnej sutannie zbierający składki na pismo dla sług katolickich, czy pomięty, zgorzkniały hrabia, który z niesmakiem daje składkę na owo pismo... dla lokai. W głębi, w tle salonu przesuwaja sie pozostałe "gentelmeny z mdłego Cosmopolis, fraki i smokingi bezlicowe, którym zwierciadło twarzy chyba nie powtórzy; wejrzenie poprawnie nijakie, nienagannie żadne; ten stołeczny patrycjat użycia, bezkręgowce miękkie, których najburzliwsza fala miękko niesie..." ku nicości.

Steruje nimi gospodarz-baron, ,gorzko uprzejmy, grzecznie wyniosły, ubrany Z wyszukaną sztywnością: wszystko jakby martwiało na tym człowieku, niby na uroczystość żałoby dworskiej”. On to jeździ do Petersburga, do miarodajnych czynników, on zwozi koncesje i koncesyjki, organizuje większe transakcje placami miejskimi, planuje $z$ kapitalistami zagranicznymi budowę kolei objazdowej, a wszystko pod płaszczykiem „spółek obywatelskich” czy akcji dobroczynnej jakichś tanich herbaciarni czy przytułków dla starców. Ostrożnie, pod obsłonkami i pozorami posuwa się drobne materialne sprawki osobiste i na ich marginesie, „dla przyzwoitości”, jeszcze błahsze sprawy społeczno-filantropijne.

„I na co to wszystko? - pyta pułkownik, jeden z porte-parolów pisarza. - Po co tak przechytry krok ich tu każdy? Jakie sprawy tu zawiłe, jakie losy się tu ważą? Po co te przyjaźnie, świadczenia, obłudy? Te stosunki szerokie, te sławnych śpiewaków po salonach prezentacje, te sesje o sprawach publicznych i cała ta szkoła dyplomacji... parszywej" - by zdobyć parę korzystnych koncesji finansowych? - parę wygodnych robótek dla dalszej gnuśnej egzystencji ślimaków w zatęchłej, stojącej kałuży?

Ale „wy tu nie tylko na swoją niemoc chorujecie - dodaje pułkownik - lecz i na Rzymu zgrzybiałość, na Francji zniewieściałość, na Niemiec gruboskóre zmaterializowanie... Czarci wszystkich nacji swarzą się o duszę waszą”. - A dochodzi jeszcze potrójna trucizna „łaski $-\mathrm{z}$ wschodniego samowara, wschodniego papierosa i wschodnich doktryn".

„I cały wir ludzkich tu obcowań wydał się zamętem ogromnego znużenia, wyczerpania wszystkich podniet gromadzkiego życia, stłoczonego w ramy za ciasne, kłębowiskiem sztucznych niepokojów, sprowadzoną z obcych stolic gorączką wielkomiejską bez ognistej gorączkowej woli, które tamto życia przepala”.

W tę zatęchłą, duszna atmosferę bogatego sfilistrzałego mieszczaństwa pada piorun mobilizacji, wybuch wojny. Następuje popłoch, osłupienie, zupełna niemożność ogarnięcia powagi chwili. I oto zapodziewają się gdzieś jak nietoperze o przedświcie, giną w pomroku zapomnienia wszystkie te cienie ludzkie, rozpełzają się 
w popłochu po swych domostwach, dziwnie jeszcze pomniejszone, spokorniałe i pobladłe.

I wtedy, po zniknięciu ich niby brudnych śniegów - pozostaje Ozimina, ci, którzy noszą w sobie ziarna jutra. Byli oni i przedtem w glebie warszawskiej, przesłaniani jednak przez miękką, oślizgłą masę wierzchnią.

Do „kłosonośców” należy o profilu orlim, w dziób ptaka zarysowanym, sędziwiec, weteran dawnych walk. „Kampanię trzydziestego roku odbył jako oficer. Majorstwa dosłużył się na Węgrzech pod Bemem. Za Garibaldiego niósł wolność Neapolowi, tamże ranny. Brał udział w 63 roku. Bił się jako ochotnik w wojnie francuskiej, $\mathrm{w}$ franctireurach. Potem walczył w armii wersalskiej pod generałem Dąbrowskim Jarosławem. Komunard”. On pierwszy wietrzy wybuch wielkich wydarzeń czujnością starego polityka, żołnierza wolności na wszystkich frontach Europy. On pierwszy dojrzy usuwanie się potęgi caratu („Przyszło i na was. Wojna to zawsze rozpoczyna... Po całej ziemi waszej pójdzie”). On jest żołniersko-ludzkiej tradycji wierny a wolny duchem, emigrant-Europejczyk nie zapomni o pożegnaniu się z pułkownikiem - Moskalem-wrogiem, ale idącym na wojnę.

Obok niego stoi jego syn czy bratanek, który w dziewiętnastym roku swego życia bił się w lasach w r. 1863, a potem żył długie lata w nieustannych buntach, ucieczkach i spiskach, po katorgach Sybiru wieczny tułacz-konspirator, brodaty olbrzym, w którego szerokiej, gorącej piersi kotłuje się już wiele wichrów wschodnich. Urodzony „buntowszczyk”, należący do tych, „którzy z całej swej natury tak bardzo muszą, że się o powodzenie z losem nie targują. Dla których dostatecznym powodem jest własna dusza. Tacy zostawiają i siebie, i swój cel dla podjęcia lub podeptania przez innych. Nie bacząc nawet, czy tym korzyść, czy klęskę przyniosą... innym". Znajdą się w każdym buncie, w każdej manifestacji, żywe symbole nieustannego protestu.

Trzecim kłosodajnym ziarnem jest wątła kobieta o gruźliczych wypiekach, tajna nauczycielka, chodząca po suterenach i mansardach robotniczych, ucząca za darmo straszliwą zbieraninę młodocianej nędzy i występku, tropiona przez szpiclów za zbrodnię oświecania maluczkich, poniewierana po aresztach, na Pawiaku czy w ratuszu. Głodna, zaniedbana, uparta, zaciekła do ostatniego tchu, nieustannie sieje ziarno oziminy w brudne - zdawałoby sie - błoto, a przecież po prostu w rozpulchnioną, chłonną, zmierzwioną glebę ludzką.

Czwartą wreszcie żywotna postacią w powieści jest Nina, przedstawicielka młodzieży warszawskiej, nowej, nie wciagniętej jeszcze w orbity żadnych prac, ale bujnej, gorącej, żądnej wielkich wysiłków, nieufnej wobec romantycznych gestów czy męczeńskich ofiar, ale już cała żywotnością instynktu jeszcze bardziej odepchniętej od bierności i małostkowości starego pokolenia.

Ci ludzie oraz wierzenia, w które oni wierza, i prawdy, którymi żyją, to są owe „vitae lampadae traditae”, życia pochodnie przez pokolenia sobie oddawane, które pisarz ukazuje - jako run świeżą - pod rumowiskiem mieszczańskiego zakłamania w dosycie i gnuśności bez jutra.

Niespokojne, bujne, młode, zielone, świeże, nadchodzące jutro będzie nawiązywać do życia i czynu tych ludzi właśnie. Oni jedyni w poczynaniach swoich znajdą „czucie $z$ duszą ludu”. $Z$ nimi stana „,robotnicy, studenty-wagabundy i ambitne po czwartakach niedouki” - „A pamiętacie - mówi jeden $z$ tych mistrzów zebrań 
konspiracyjnych - jak to Jędrzej Niemsta z Kęt przyszedł do nas po raz pierwszy, jak we drzwiach niepotrzebnie $z$ wsiowego nawyku łeb chylił i nogę podnosił, niby próg chałupy przestępując i jak w ten nasz szwargot zagadywania wszystkiego wygłosił od proga, samemu sobie tym przyjściem do nas uroczysty i jakby namaszczalnie spokojny: "Niech będzie pochwalony Jezus Chrystus". I tylko krawczyna jeden jękliwy porwał się był z miejsca, zapatrzony w tę chłopską sukmanę, krztusił się, krztusił językiem w gębie i wyrzucił nagle w ogniu twarzy całej: "Na wieki wieków. Amen". - Tak się te dwie "dusze" odrębne przywitały przy nas. I właśnie z ich to zahaczenia się uczuciem szedł jakby spokój w ogniu, ład w alarmie i wytrzymałość kamieni".

Tak to nie w literackich i artystycznych hasłach i polemikach, ale w elementarnym, podstawowym, prostym i ciagłym trudzie i męce żywego przykładu usiłowała wtedy inteligencja $\mathrm{w}$ Warszawie $\mathrm{w}$ przełomowych latach między wiekami związać martwe myślą, żywe instynktami „doły” narodu z odpowiedzialnością wobec przeszłości i wobec - przyszłości. Tak wschodziła „ozimina” wolności pod rozsypującym się próchnem butwiejącego, bogatego mieszczaństwa.

\section{[Bez tytułu - o Wietrze od morza Stefana Żeromskiego]}

Twórczość Żeromskiego w nurcie rwącym, niespokojnym i głębokim a pełnym wirów nie daje się ująć i zgłębić łatwo. Ledwie ustali się kierunek biegu - niespodziewany skręt myli badacza; liczne mielizny usypiają czujność wobec sąsiadujących z nimi tuż głębin i przepaści. A przecież mimo zmienności i różnorodności jest także ta twórczość dziwnie jednolita, z rzadką zaciekłością wraca często do tych samych spraw, stosuje podobne uderzenia, niesie podobne myśli, obrazy, nastroje, nawet postaci.

Wiatr od morza, pierwsza powojenna powieść Żeromskiego, przynosi szczególne trudności. Różni się ona bardzo od jego wielkich powieści sprzed roku 1916; różni się od tematyki pisarza przeważnie współczesnej, pozbywa sie niemal zupełnie czynnika akcji, tak na ogół sprężonej i dynamicznej w dawniejszych powieściach pisarza, omija prawie całkowicie duszoznawcze, psychologiczne jego dociekliwości.

Niemniej wiąże się ta książka blisko z „całobiegiem” pisarstwa Żeromskiego, co jednak dopiero musi być celem rozważań.

Drugą trudność nasuwa dziwna kompozycja tej książki. Składa się na nią kilkanaście opowiadań, nowel i opisów, złączonych dość przypadkowo pod jednym dachem tytułu. Nie tylko zagadnienia i kompozycja każdego fragmentu są różne, ale i styl patetyczny, oparty o prozę rytmiczna, znamienny dla ukazywanych przez pisarza czasów pradawnych, sąsiaduje z oschłą rozprawą historyczną, a wypukły, soczysty realizm $z$ nieomal sprawozdawczym reportażem. A przecież to nie miscellanea, zbiór samodzielnych całości zbieranych $\mathrm{z}$ różnych lat, ale dzieło najdojrzalszych lat znakomitego pisarza. Nasuwa się wciąż pytanie, co w istocie łączy ze sobą te porwane fragmenty - i czy są one porwane?

Odpowiedź na to pytanie pozwoli zarazem wejrzeć w głąb tej książki, a jednocześnie w głąb pierwszego okresu twórczości Żeromskiego po Wielkiej Wojnie. 
Już na pierwszy rzut oka spostrzec można trzy czynniki, które są wspólne całej książce.

Pierwszym jest postać Smętka, ostatniego z długiej serii demonów, z którymi walczył Żeromski - przewija się ona przez większość rozdziałów, od pierwszego do ostatniego.

Drugim czynnikiem jest jedność, a ściślej: łączność czasu; fragmenty ułożone są chronologicznie, ukazują wydarzenia między ludźmi w kolejności lat i wieków.

Trzecim wreszcie elementem jest jedność miejsca; wszystkie wydarzenia odbywają się na szczupłym skrawku u delty Wisły od Żarnowieckiego Jeziora do Fromborka i od Helu do Kwidzynia.

Każdej z tych spraw trzeba się przyjrzeć oddzielnie.

Walka ze złem i walka z szatanem była zawsze zawołaniem rycerskim Żeromskiego. Ale pojęcia zła i szatana nie były równoznaczne. Szatan to mitologizacja zła, jego uosobienie, a zarazem koncentracja i dynamizacja: to jakby obdarzenie zła intencją szkodzenia, czyhania na dobro. Pojęcie szatana jako władcy zła nie było właściwe wszystkim czasom i wierzeniom. Choćby w mitologii greckiej bywali bogowie rozzłoszczeni, ale nie było bogów zła. Harpie i Minotaury były demonami miejscowymi o czynnościach i zasięgu ograniczonym do typu jakichś szczególnie drapieżnych zwierząt; a zresztą należały do pozostałości kultów dawnych, przedolimpijskich.

W kręgu kultury staroperskiej Bóg zła, ciemności, nocy równy był Bogu dobra i słońca, z którym toczył wojnę ciągłą, różnił się więc w swej równorzędności od pojęcia demona. Dopiero w judaizmie i w chrześcijaństwie (także w hellenizmie) jak wiadomo - szatan, wcielenie zła, zajął poważne miejsce, chociaż dalekie od wszechpotęgi Boga. W Starym Testamencie raczej przybierał postać antycznego giganta, stracconego z nieba, buntownika, w Nowym - występował głównie jako kusiciel. W przebiegu wieków różne zresztą przebywał koleje, pojawiał się w sądach ostatecznych, wśród chimer katedr, w tekstach misteriów, aż zszedł na marginesy katechizmów dla dzieci. Ostatnie odblaski swej potegi ukazał w dziełach literackich od Goethego, Byrona i Mickiewicza po Ibsena, Hauptmanna czy Kasprowicza w okresach symbolizmu i neoromantyzmu.

W tej ostatniej epoce, tak bogatej w lucyferyzmy, pojawił się także u Żeromskiego.

Obok głównego nurtu zła są w twórczości pisarza różne odnogi i rozwidlenia. Jedna z tych bocznic przepływa przez dramat o Sułkowskim, ukazuje spiżowa maskę Colleoniego w Dumie o hetmanie, by najpełniej wcielić się w Bożyszczu (Róża). Bohaterom zagląda w oczy zło jako pokusa władzy, rządzenia ludźmi i ludami, nawet elementami ziemi.

Inne zło, brutalne, odarte zupełnie ze znamion nadludzkich, ukaże się w Dziejach grzechu.

W opowieści Aryman mści się bohaterem jest - jak wiadomo - pustelnik Jan, syn starego Pustelnika, który kazał mu żyć na pustyni, z dala od ludzi i świata. Gdy syn odtrąca kochającą kobietę i ta umiera, nagle spostrzega on swój błąd 
i wyciaga ręce ku mogile ojca: „Przeklęta niech będzie miłość twa do mnie. Straszny i okrutny dla mnie był duch twój. Łakomy zżeraczu i tępicielu szczęścia, czemu nie poszedłeś do szatana uczyć się - dobroci? Dobry jest szatan. Niech będzie błogosławiony szept jego".

W tym pierwszym objawieniu się szatana dwa rysy są ważne i dla Żeromskiego znamienne. Pierwszy, że nazwał go poeta Arymanem, a więc kimś równoważnym Bogu dobra, a więc wszechpotężnym. Drugi, że bóg nocy i zła jest tu bogiem szczęścia, miękkości, łez, pogody i uroku, a bóg dobra i jasności bóstwem okrutnym, twardym i ponurym (Aryman jest tu pokusą świata).

To charakterystyczne pojęcie dobra i zła przepływa przez wiele utworów Żeromskiego, zwłaszcza wcześniejszych (od Ludzi bezdomnych, przez Popioły, Sułkowskiego, do Urody życia, jakże znamiennie zatytułowanej). To zło sprowadza człowieka $z$ wielkich, górnych dróg życia.

Już od najwcześniejszych jednak dzieł płynie także inny nurt w twórczości pisarza; zło zostało tam związane najbliżej z obrazami i pojęciami krzywdy, wyzysku, niezawinionego cierpienia, nędzy, pohańbienia, zbrodni. Wszędzie, gdzie człowiekowi jest źle przez innego człowieka - istnieje zło. Nędza, strach, cierpienie nie tylko same są złe, same przez się, ale zginają kark człowieka, łamią wzrost, zmuszają do życia przy ziemi, odwracają od wzniosłości, są złe w potędze drugiej. Do walki z tym złem staje Siłaczka i dr Piotr, Radek i Judym, i Korzecki, a wreszcie Nienaski. W trylogii Walka $z$ szatanem, jako najważniejszej w tym nurcie twórczości pisarza, zło, ukazywane poprzez udręki sumień chrześcijańskich, krystalizuje się w pustelni i ukazuje swą twarz w obrazie przeora albertynów, zatytułowanym Kuszenie Chrystusa.

Tak opisuje ten obraz Nienaski: „Oczy szatana, wszechwiednie mądre, dosięgające dna rzeczy, a jednak smutne... patrzyły w białego Chrystusa. Włosy szatana były długie i siwe, twarz stara, strudzona - znać niezgłębione cierpienia, furie i tortury duszne ryły ją i wykrzywiały przez nieskończoność".

Nie w krasie i uroku pojawia się tutaj zło, ale jako wcielenie świadomości cierpień i katuszy życia. Cóż może obiecywać, czym kusić władca nędzy i rozpaczy? A przecież - może wysunąć najstraszniejszą z pokus - pokusę rezygnacji. Tak było, tak jest, tak będzie, tak musi być. Jak wiemy, Nienaski nie uległ tej pokusie.

Następnym chronologicznie wcieleniem zła był w powieściach Żeromskiego właśnie Smętek z Wiatru od morza. Pojawia się on wkrótce po Walce z szatanem. Postaci tej trzeba się przyjrzeć nieco bliżej niż obliczom rysującym się w dziełach poprzednich.

Przeszedł on do powieści $z$ baśni kaszubskich (zapewne poprzez książkę B. Chrzanowskiego), gdzie biesi się $w$ wichrach razem $z$ innymi biesami regionalnymi, nie wyróżniając się niczym. Kształt swój zewnętrzny w powieści zawdzięcza zapewne rzeźbie Der Flissaque, stojącej w okresie międzywojennym na dziedzińcu ratusza w Toruniu. Pomnik uderzać mógł widza połączeniem postaci bosego flisaka nie $z$ godłami wioseł czy sieci rybackich, ale ze skrzypkami w skręcie namiętnej gry.

Znamiennym rysem Smętka u Żeromskiego jest, że pojawia się on najczęściej jako muzyk. Już w pierwszym ataku Skandynawów na Oksywie towarzyszy im pieśnią skalda. W drugim fragmencie tańczy wśród drapieżnych zwierząt na górze 
żarnowcowej, grając na ligawce i śpiewając. A św. Wojciechowi ukazuje się jako bosy przewoźnik wiślany, który, o dąb oparty, gra na normandzkiej wioli. W związku ze znaną wrażliwością Żeromskiego na rzeźby (Colleoni, Dawid, Wenus milońska, chimery z Notre Dame) - wpływ tej rzeźby jest prawdopodobny.

Ale $z$ kształtem zewnętrznym wiąże się charakterystyka wewnętrzna tej postaci. Gra Smętka nie uspokaja, przeciwnie: rozdrażnia, podnieca, rozżarza do czerwoności. Już w pierwszym fragmencie „Porywał, podniecał, unosił i gnał pędzących ni to bat świszczacy śpiew skalda młodego... Wrzało w tej pieśni męstwo nieustraszone i pasja szukająca niebezpieczeństw. Pieniła się nieposkromiona siła... nieubywająca żądza”. Ten sam ekstrakt drapieżnej żarłoczności współgra z jego złowieszczym tańcem $z$ wilkiem, jastrzębiem, żmiją i łasicą.

On w czasie wojny rozżarza okrucieństwa do ekstaz dzikości: „wyrywać szponami wnętrzności z brzuchów, wykłuwać źrenice omdlałe, odłamywać żebra aż do bioder..."

A w czasie pokoju on, Smętek, zapala młódź rybacką do nocnych korsarskich napadów, u starych podnieca żądze myśliwskie, a przed oczyma kobiet przesuwa powaby miłości sekretnych. Wszystko, co dzikie w człowieku, podnosi poza granice zapamiętania, aż do szaleństwa i okrucieństwa. Inne cechy Smętka występuja ubocznie, rzadko wobec tej naczelnej: rozżarzenia dzikości i zachłanności samolubnej...

Po przypomnieniu najznamienitszych cech wcielonego zła można spróbować $z$ dać sobie $z$ nich sprawę $w$ skali szerszej.

Przede wszystkim zło nie jest w Wietrze od morza nieujętym pierwiastkiem świata o wymiarach kosmicznych. Wcielony w określona postać antropomorficzna, pokazywany nieraz, diabeł ten niby się kurczy i zatraca wymiary metafizyczne jakiegoś Arymana.

Po wtóre - działa tylko na Pomorzu, straszy, zwodzi, gnębi przez wieki, ale tylko na przymorzu kaszubskim. Znowu nie ma wymiarów kosmicznych, staje, ot, blisko Minotaura.

Po trzecie, jego wpływ odbywa się gdzieś na pograniczu psychologii i fizjologii człowieka oraz zwierzęcia, a nie - w kosmosie w ogóle.

Po czwarte wreszcie, szatan zostaje w rezultacie - wypędzony. Wprawdzie już $\mathrm{w}$ Walce $\mathrm{z}$ szatanem spotyka go niejedna klęska, ale tu zostaje po prostu sromotnie wygnany.

Kiedy więc rozbierzemy występujące $\mathrm{u}$ Żeromskiego pojęcia zła $z$ diabolicznych masek i kostiumów, spostrzeżemy - nawet w tym szkicowym ujęciu - stopniowe zatracanie przez zło swego ciężaru gatunkowego. Przestaje być równoprawnym, koniecznym składnikiem świata jak przy pierwszych manichejskich tendencjach pisarza, przechodzi przez uparte walki w głębi sumień - jako satanizm chrześcijański, aż staje się półpogańskim, wpółludowym biesem, którego można przepędzić z ziemi. Nieraz chłop przechytrzył i wygnał czarta, jak w kaszubskiej bajce opowiadanej Fryderykowi II. Nie ma jednakże Smętek rysów wpółkomicznych, właściwych nieraz legendom ludowym; jest rzeczywiście zły, okrutny, przebiegły, drapieżny, ale nie panuje nad człowiekiem, tylko podżega, judzi, rozżarza instynkty i żądze tkwiące w ludziach. Nie jest władcą ciemności.

Widzimy w najgłębszych pokładach twórczości Żeromskiego stopniowe przesu- 
wanie się i odsuwanie lodowców pesymizmu, nieuchronności nadludzkiego ciężaru zła, zbliżanie się do zła w skali człowieka.

Żeby wytłumaczyć pełniej przypływ w dziełach tego okresu fal względnego ciepła, odpływ - zreszta niepełnego - pesymizmu, trzeba sięgnąc do innych warstw powieści.

2

Już w pierwszym obrazie ksiażki rysuje się wyraźnie przeciwieństwo dwóch sił zmagających się ze sobą na ziemi pomorskiej.

$Z$ jednej strony dzicy, zuchwali żeglarze, którzy lądując na łodziach wikingów i widząc osiedla, „dali się porwać furii krwiożerczego instynktu. Nienawidzili oni osiedzicieli tej strony, zanim ujrzeli dym ich ogniska. Nienawidzili ich pracy i ich snu, nienawidzili ich pokory i wybiegających z pokory względem ludzi podstępów nieskończonych względem zwierząt, ryb, ptaków i owadów".

Po stronie najeźdźców, „których jedynym zajęciem była żegluga, wojna i rabunek” postawił Żeromski Smętka, wcielenie „nieposkromionej siły, nieukojonej żądzy, dumnego piękna łamania wszelkiego zakazu oraz nigdy nie nasyconego pragnienia widoku walki człowieka $z$ człowiekiem".

Po stronie pokornych a przebiegłych prostaków, ,zgarbionych w pracy około zasiewów, doglądania żniwa i omłotu prosa, zbiórki jagód i grzybów czy łowienia ryby" - postawił autor swe czujne sumienie.

Spójrzmy najpierw na jedną stronę, stronę Smętka.

On to, który przybył ze Skandynawami, ,wszelkimi sposobami pobudza żądze, psuje spokojną krew", oszustwami i gwałtem uczy łamać prastare zwyczaje łowieckie, rybackie, bartnicze. Za nim i z nim idą opaci, przemieszani ze szpiegami, rycerze $z$ katami - i tak od czasów Gerona. On to, Smętek, później w postaci sekretarza Graffiacane (imię diabła z Boskiej Komedii), przeważa skrupuły wielkiego komtura Henryka von Plotzke, aż ten wreszcie łamie swe zasady moralne, religijne, depce prawa rycerskie dla zysku Zakonu i napada nocą na bezbronny Gdańsk, wyrzynając bezbronnych mieszkańców. Inne, nie mniej przecież „demoniczne” rysy cechują zakonników jerozolimskich: „o duszach przemyślnych i zawikłanych, które poznały się na wschodzie $z$ tajnym zamysłem i sekretnym pchnięciem”. Jeszcze inne rysy ujawni pisarz w tym fragmencie, w którym Wielki Mistrz krzyżacki targuje się $z$ margrafem brandenburskim o ilość tysięcy grzywien za ziemie między Łebą a Wisła. Wyszachrowane obłudnie przywileje cesarskie odstępuje się tam wraz z ludnością, miastami i wsiami, zamkami i kościołami, zwykłym aktem handlowym kupna-sprzedaży.

A w opowiadaniu o Fryderyku II ukazana jest pasja tego króla, gdy po pierwszym rozbiorze zwiedza Pommern, „ów kraj pusty i próżny o rasie bydła zwyrodniałej, o narzędziach rolniczych pierwotnych, drewnianych, gdzie role pełne zielsk i kamieni, wsie złożone $z$ chałup dymnych". W tej pasji podpisuje Fryderyk dekret „o wywłaszczeniu właścicieli, którzy w Polsce przemieszkiwać chcieli”, drugi „zabraniający wstępu chłopom polskim na ziemię pruską", trzeci o asygnacie wielkich sum na osadnictwo niemieckie. Praca, przywiązanie do ziemi, obyczaj, prawo, zasada nie znaczą nic - wobec interesu i racji stanu.

Powstaje pytanie: co może łączyć ze sobą te obrazy i nowele tak bardzo odmien- 
ne? A przecież w najgłębszym ich jądrze jest coś „wspólnego”. Oto ukazany w nich jest „nieludzki” stosunek człowieka do człowieka, do narodu, do ziemi, do świata. Nieludzki - a więc drapieżno-zwierzęcy, stosunek wilków, jastrzębi, żmij i wszelkich grabieżców. Nieludzki - a więc także handlowy, kupiecki, „polityczny”, stosunek szalbierza, handlarza żywym towarem, statysty, który ziemiami, ludźmi, obyczajami, przeszłością targuje, sprzedaje, usuwa, przenosi z miejsca na miejsce, jak rzecz martwa, jak cyfrę w rachunku.

Że tak jest, że taka ocena jest jedną z najmocniejszych nici zszywających luźne arkusze tej dziwnej książki Żeromskiego w całość-dzieło, świadectwem jest jedna z końcowych nowel: o Ottonie von Arffbergu. Ta, odbiegająca tak od innych fragmentów, współczesna nowela, przedstawia romans kapitana niemieckiej łodzi podwodnej w rodowym jego pałacu ,in Pommern”. Nie ma w niej ani śladu napomknień historiozoficznych, opisów historycznych czy etnograficznych, walk Polaków z najeźdźcą, którymi tak przepełnione są inne fragmenty. Ale... szalone ekstazy zmysłów, które łączą młodego kapitana podczas krótkiego urlopu wojennego z młodziutką bratową ledwie w parę tygodni po śmierci brata na froncie, obok jego mogiły - noszą wszelkie cechy miłości „nieludzkiej”. Można ten wybuch zmysłów wyjaśnić gorączką wojny, wstrząsem po katastrofie rodzinnej, przeczuciem śmierci - a przecież jego czysta, jak czysty alkohol, przeżerająca, spalająca siła dziwnie łatwo kojarzy się z późniejszym twardym spokojem młodego kapitana podczas dwukrotnego storpedowania pasażerskich statków czy z zimna jego brutalnością wobec bezbronnych jeńców francuskich. Łącza je rysy - nieludzkie. Nie zboczenia to, związane $z$ ludzkimi namiętnościami czy słabostkami, ale wydestylowanie psychiki z poczucia wspólności z ludźmi, żywymi czy umarłymi, wrogami czy przyjaciółmi, $\mathrm{z}$ honorem i obyczajem, ze wszystkim co - ludzkie.

I tu wolno wtrącić jedną uwagę. Szereg pokoleń niemieckich przeżerało pragnienie „Übermenscha”. Obojętne, czy zwolennicy i wielbiciele Nietzschego będą z tym pojęciem wiązać treści „nadludzkie”, a przeciwnicy raczej doszukiwać się rysów „podludzkich”; w każdym razie i niewątpliwie pragnienie to jest próbą wyjścia poza człowieka, jest więc pozaludzkie - nieludzkie. Jenseits von Gut und Böse. Nie wymawiając nigdy tych wyrazów, nie zbliżając się może nawet do pojęć, od początku do końca swej książki Żeromski ciągle ociera się o treść nieludzką w człowieku, $\mathrm{w}$ narodzie i w historii. I to jest centralnym zagadnieniem książki: prześwietlenie i wymazanie z człowieka składników obcych, wrogich, nieczłowieczych.

Przeciw owym siłom złym, krzewiącym się poza etyką i psychiką człowieka, stanęła na ziemi pomorskiej od pradawnych czasów „potęga nieznana, wychylała się ona $z$ ciemnego, tajemniczego wschodu, oparta o nieprzejrzane, niewiadome i niezliczone w lasach polany”. Skład tej siły tworzyli oni, ,prostacy zgarbieni w pracy koło ziemi”, a też ci dawniejsi „śmiali karczownicy, którzy z prapradziadowską siekierą w dłoni ruszali w tajne ostępy, ażeby je przetrzebić, równać i do góry spodem leśna glebę odwracać”. Tworzyli tę siłę tysięczni i setnotysięczni, bezimienni, uparci jak żywioł „Polanie”, ludzie pól i polan, co latami i pokoleniami, jak falami, wciąż podchodzili ku morzu.

Wcieleniem najprawdziwszym i najczystszym bezimiennych milionów jest w Wietrze od morza stary, niemal stuletni Wyszka Zamk Trzebiatowski znad Żarnowieckiego Jeziora. Poważną radością ujmuje on świat wokoło siebie. Oto miał 
przed oczyma drzewiny sadu za domem. Jakże głęboko miłował te bezmowne, przedziwne istoty, które za trochę opieki i czułości płacą nieprzeliczoną nadwyżką kwiatów, owoców, zapachów. Tak patrzy na każdą jabłoń i gruszę, tak wspomina tkliwie po latach wiernego psa.

W tym roboczo-gospodarskim, opiekuńczo-patriarchalnym, życzliwie spokojnym odnoszeniu się do roślin i zwierzą, do ludzi i ich spraw wyraża się całkowicie odmienny, swoisty gatunek człowieka; gatunek, który wyrósł ze stuleci pracy rolniczo-hodowlanej. Jego treść najgłębszą, jego istotę zamknął Żeromski w modlitwie, którą włożył w usta tegoż sędziwego gospodarza:

„Niech każdy idzie za klękiem pługa, każdy wzdłuż bruzdy swojej, po ziemi nieprzemierzonej, która za trud płaci tylą miłości! Niech pokochają zwierzęta domowe, towarzyszów dostojnych, wiernych i zacnych. Niech pokochają kwiaty i drzewa, zboża, jarzyny, liście i kłosy ścięte, niewinne i tak wiecznie bez odmiany uczciwe. Niechaj nareszcie uszanują świętość dzieci i trud przodków umarłych. Niech oddadzą sprawiedliwość pracy wykonanej”.

Tak brzmi głos milionów, przygarbionych w rzetelnej, ciagłej a spokojnej pracy ku ziemi.

Obok Wyszki ukazał pisarz w Wietrze od morza cztery jeszcze postacie. Jedna to apostoł Pomorza, męczennik, św. Wojciech, a w nim wcielona „praca nieustanna, wytrwała, w każdej minucie $\mathrm{z}$ tym samym podejmowana męstwem, ażeby pokonać w sobie zwierzę, rozpustnika, łotra, zbójcę... wysiłek wieczny, ażeby być nieznanym, zapomnianym, być $z$ dala od wszystkiego, co jest sława, być pokornym, być cichym, być niczym, być sobą samym, być dobrem dla dobra, być uśmiechem i w łasce”.

Druga to wielki syn Torunia, Kopernik, który wielkim wysiłkiem całego życia oddzielił światło prawdy od mroku złudzenia. Znamienne, że i jego kusi Smętek, kusi rozpaleniem żalu za uchodzącym życiem, wyrzutami, że nie zgarnął nic ze świata ku sobie, ale dawał od siebie.

Trzecia to półlegendarny Jan z Kolna, śmiały żeglarz, odkrywca nowych lądów. $Z$ dziesiątkiem cieśli, stolarzy, kowali, wbrew przyziemnym interesom chciwców długie miesiące $\mathrm{z}$ zawziętością żarliwą budował swą galeonę do skoku przez ocean, choć „nie ciagnął go tam handel, interes, zysk pewny, nagroda”.

Czwarta postać - to generał Dąbrowski, co na czele legiów z ziemi włoskiej po wieloletnich walkach, załamaniach i zawodach przybył pod mury Gdańska, by oglądać dzieło sprawiedliwości dziejowej. Oto dziesiątki obcych ludów, które kiedyś obojętnie patrzyły na tragedię rozbioru Polski, krwią swoją potem odrabiają w armii napoleońskiej zbrodnię wykonaną przez Prusy i zbrodnię swej obojętności.

I znów powstaje pytanie: co łączy tych czterech tak różnych ludzi - świętego kapłana z zuchwałym żeglarzem, uczonego z wodzem? Otóż najpierw nie było w nich drapieżnej żarłoczności, nie ciagnął ich - powtórzmy - „interes, zysk pewny, nagroda”. Nie „do siebie” garnęli świat, ale „od siebie” dawali otoczeniu; po wtóre, dzieła ich wyrastały z pracy całego życia ciężkiej, wysilonej, ciągłej i do dna uczciwej, nie opartej ani o krzywdę niczyją, ani o łatwizny podstępu czy przypadku. Wreszcie wszyscy szli ku sprawom wielkim, doniosłym; przyświecały im w życiu skupionym i surowym takie hasła, jak: czystość życia, prawda wiedzy, prawda odkrycia i wreszcie sprawiedliwość historyczna, nadnarodowa. 
Wszyscy czterej wyrośli wysoko i głowa, i sercem, i szerokością mocnego oddechu ponad swych współczesnych, ale przecież wyrośli $z$ jednego gruntu, $\mathrm{z}$ jednego wspólnego gatunku człowieka. (Znamienne, że pisarz nie wprowadził polskich królów, hetmanów, wojewodów, reprezentantów polityki i władzy, a jedynie żywioł ponadaktualny, trwały.)

Można by, oczywiście, zauważyć, że pisarz idealizuje w swej książce jedną stronę, a przeczernia drugą. Ale zarzut ten byłby słuszny tylko częściowo.

Istotnie, książka ta zbyt wcześnie powstała po Wielkiej Wojnie, aby krew w niej płynąca mogła się uspokoić zupełnie. Ale pisarz nie dał się zaślepić. Nieraz udziela barw jasnych stronie ciemnej, a cieniów - stronie jasnej. Bezmiar odwagi wikingów, żelazna wytrwałość i konsekwencja rycerzy zakonnych, zmysł organizacyjny, cywilizacyjny Fryderyka, a nade wszystko krasa i uroda życia, jaka cechuje niemal wszystkie wcielenia i dzieła Smętka, ,tak celowo nieomylne jako rzut skrzydeł jastrzębia", są ukazane ze szczególną siłą, zbliżoną do specyficznego rodzaju zewnętrznego zachwytu.

A znów gnuśna ciemnota, zabobony, małostkowość tradycjonalizmu, które nieraz cechują życie polskie, spotykają się zawsze z pogardą i potępieniem autora.

Wreszcie zrozumiała jest rzecza, że w obu wypadkach chodzi jedynie o najgłębsze i dominujące siły, a nie o charakterystykę wszystkich przedstawicieli jednej i drugiej strony. Za wielkim, za głębokim pisarzem był Żeromski, żeby sobie pozwalał na taniość propagandy. A jednocześnie był w dobie pisania Wiatru od morza w pełni dojrzałości twórczej - musiał więc wyrazić tu istotne, głębokie pokłady swej indywidualności.

Od czasu Grobu Agamemnona nikt tak jak Żeromski nie targał sumieniem polskim, nikt tak nie rozdrapywał blizn, by nie zarosły błona podłości. Dlatego nie wolno go posądzać o łatwy nacjonalizm. Po prostu pisarz stawiał sobie w tej książce inne cele: zwrócił się twarzą przeciw człowiekowi „obcemu”, przeciw „obcości” w człowieku, opierając sie na prawdach najgłebszych, dobytych z polskiej ziemi i z polskiej historii.

W dziele tym pisarz z najczystszą żarliwością swego umysłu i „serca nienasyconego” zmaga się z siłami, które uważa za „nieludzkie” w człowieku, w narodzie, w kulturze, w świecie; choćby owe siły mogły się z jakiegoś względu nawet podobać, tropi je na każdym miejscu, ukazuje i piętnuje. A zarazem walczy w obronie wartości ludzkich, nawet jeśli one łączą się niekiedy z grzechami czy błędami, ale „ludzkimi”. W tym sensie jest Żeromski w swej książce ponadnarodowy i ponadczasowy, jest pisarzem głęboko humanistycznego uniwersalizmu, walczy bowiem o pewien typ człowieka i pewien typ życia. I to jest jedna podstawa wartości Wiatru od morza.

A jednocześnie, wcielając i ukazując jeden gatunek życia w kształtach germańskich, krzyżacko-pruskich, a drugi - w kształtach narodowych polskich, starał się Żeromski ująć istotę dziejów Pomorza, ukazać oblicze duchowe tej ziemi, na której oba te prądy, obie odmienne postawy życiowe ścierały się ze szczególną wyrazistością. Tu jest drugi filar wartości dla nas tej książki, próbującej określić wewnętrzne osiaggnięcia naszego narodu. Że nie przeciwstawia się tutaj pisarz niemieckiemu typowi życia pojętego ogólnie narodowo, dowodem, że po stronie Smętka stawia wikingów, komturów zakonu krzyżackiego (nie tylko Niemców), oficerów czy wład- 
ców pruskich, wszystko - ludzi żyjących zdobyczą, podbojem, zaborczością, a wreszcie we fragmencie ostatnim najostrzejsze słowa kieruje przeciw współczesnym Anglosasom za ich zaborczy imperializm.

Ale jeszcze jedną wartość posiada Wiatr od morza. Trzeba nawrócić do uwag wstępnych o walce Żeromskiego ze złem, jednakże nie od strony rodzajów zła, ale od strony sposobów walki ze złem.

Pierwszy sposób to droga anachorety (Aryman mści się). Sposób ten Żeromski odtrącił; pogarda świata objąć może także pogarde piękna, dobra czy wielkości, które są na świecie, a $z$ tych wartości pisarz rezygnować nie chce. Broni tego sposobu (ascezy, surowości życia), ale i zmaga się $z$ nim wewnętrznie w dziesiątkach utworów.

Drugi nurt walki $z$ szatanem przyniósł inne rozwiązanie: pustelnikom Nienaski rzuca swoje hasło: „idę robić pieniądze”. I ta formuła, w różnych kształtach, przewija się w licznych utworach Żeromskiego. Czy jako nowa straszliwa broń (Róża), czy nowy samolot (Uroda życia), czy fortuna - najczęściej - jest to zawsze zdobywanie środków materialnych do walki ze złem. Gwałt niech się gwałtem odciska. Trzeba zdobyć arsenały ludzi złych, by je zwrócić przeciw nim.

Zbyt jednak czujnie krytyczny był Żeromski, aby nie wiedzieć, że w nabitej broni tkwi pokusa strzału, w skarbie - pokusa zbytku, we władzy - pokusa tyraństwa. I z tym podszeptem zmaga się również Żeromski wielokrotnie.

Na tym tle dopiero, w tej twórczości wrzącej, erupcyjnej, wciąż szukającej nowych wyjść ze starych labiryntów występuje w całej pełni znaczenie Wiatru od morza. Dwie tu ukazuje Żeromski strony jednej, jedynej drogi uznanej za właściwą. Przede wszystkim oparcie się o pierwiastki ludzkie w człowieku, spokojne, twórcze. A po wtóre - oparcie się o zbiorowość i czas. Całymi pokoleniami idą Polanie na brzeg morski i wypierają dosłownie i rzeczywiście zło. Setki tysięcy bezimiennych twórczych, ludzkich żywotów, setki takichże twórczych wybitnych jednostek zbiorowym, spokojnym, stulecia trwającym trudem żłobią drogę pozytywną dla nowych wartości, zacierają i gubią ślady różnych demonów przeszłości. Oto nowa, właściwa, ludzka, humanistyczna droga walki ze złem ukazana w tej powieści. Aby jednak ogarnąć całość dzieła, trzeba spojrzeć jeszcze na trzeci wyróżniony element Wiatru od morza, na czynnik tak zawsze ważny dla Żeromskiego - na przyrodę.

3

Typ i rola przyrody w dziele literackim należą często do niezmiernie ważnych, czasem nawet kluczowych, a tymczasem $\mathrm{z}$ reguły w badaniach lekceważonych czynników dzieła literackiego. Zbywa się je zazwyczaj paru gładkimi ogólnikami, jakby nie przeczuwając, że przez stosunek pisarza do tematu przyrody wyraża się bardzo często, przy tym w sposób półświadomy, a więc szczególnie cenny - zasadniczy jego stosunek i do rzeczywistości ukazywanej w dziele literackim, i do rzeczywistości świata w ogólności; nie tylko zresztą do rzeczywistości przyrodniczej.

Oczywiście tyczy się to nade wszystko takich pisarzy, jak Żeromski, w dziełach, w których przyroda tyle zajmuje miejsca.

Przed Wiatrem od morza słuszną rzeczą będzie spojrzeć na utwór Żeromskiego bezpośrednio poprzedzający tę książkę, a poświęcony wyłącznie opisowi przyrody; 
tym utworem należącym do rzadkiego typu w literaturze, zwłaszcza w prozie, jest Wisła, pisana podczas wojny.

Niewielki ten utwór, arcymistrzowska miniatura opisu, został opracowany przez Borowego w szkicu z roku 1923. Słusznie podkreślił tam krytyk, że w obrazie Wisły nie ma elementów antropomorficznych (pewne sprostowanie tego sądu będzie podane poniżej), że dominuje ujęcie biologiczno-geologiczne. Obok niezmiernie częstych obrazów sączenia się wód przez piargi czy muły z jezior, śniegowic i pieczar mamy takie zdania: „niezliczone strumienie jak włókna i nici oplotły...”, „ssące włókna Wisły sięgają...”, „w gałęziach Wisły”. Tak samo obok obrazów skał, piasków czy kredowych podłoży najbujniej pieni się świat roślin.

$Z$ widoków żaden nie został unieruchomiony na dłużej. Gwoli utrzymania płynności, zmienności naczelnego obrazu Wisły, jej narastania, przewijania się, płynięcia, przedzierania, odchodzenia - a więc ujęcia jej w dynamizmie, w rozwoju, w przepływie - pisarz szybko przesuwa przed oczami fragmenty opisów.

Nie krajobrazowo-estetyzująco, nie technicznie, nie statycznie-opisowo jako coś istniejącego, trwałego ukazał pisarz Wisłę - ale w dynamizmie procesów hydrologiczno-biologicznych.

A skoro położył autor akcent na proces narastania Wisły i jej biegu, musiał oczywiście, nade wszystko, głównie pokazać wody, wody dopływów rzek i strumieni, i bezimiennych stoków (charakterystyczne, że ukazuje je bezimiennie, nie indywidualizuje żadnego dopływu - co tak chętnie robili poprzednicy w pieśniach o Narwi, Bugu, Pilicy czy Dunajcu). A poza tym dał tylko rośliny. Gdzieś odsunął, jako czynniki nieistotne, chaty i domy, i kościoły, miasta i stolice leżące nad „osią” Polski, wszystko, co ma nazwisko. Żeromski, autor Dumy o hetmanie, Sułkowskiego i Popiołów - pisarz Polski historycznej, polskości utrwalonej w księgach, pamiątkach, tradycjach, pomnikach: obrońca kościoła św. Jakuba czy ariańskich wież - tutaj milczy zupełnie. Ledwie gdzieniegdzie, jakby na marginesie, wspomina mijane grody.

Z historii ukazuje się głównie - prehistoria, archeologia bezimienna, zarysowana często znowu w biologicznych obrazach. Drzewa nie są w stanie „przez wieków tyle wyssać soków żywotnych z popieliska naddziadów” - a gdzie indziej „niepoliczone pokłady zwłok i kości - przesycają niestrudzenie gliny i piaski”. $Z$ najnowszej historii, z toczącej się wielkiej wojny, nie ślady zniszczeń, okopy czy druty zostaja w pamięci, ale setki tysięcy ciał, co użyźniły ziemię gnojem podglebnym, cenną próchnicą. Dopiero na samym końcu książki pojawiają się sumarycznie nazwiska miast, ludzi, bitew w rejestrze suchym. I w historii więc bezimienność biologiczna wysuwa się na czoło.

Toteż gdy przyjdzie pisarzowi dać obraz wskrzeszenia Polski z odmętu wojny, nakreśli wizję rozstąpienia się wód w oceanie, spod których ukazuje się zatopiony przed wiekiem zapomniany ląd; sięgnie więc znów do procesów geologicznych.

Nim z poprzednich spostrzeżeń wysuną się wnioski ogólniejsze, warto spojrzeć na te fragmenty Wisły, które sa jakby zaśpiewem zwiastującym Wiatr od morza; będą nimi: ciepła wzmianka o Koperniku, druga o Janie z Kolna, o przychodniach z zachodu, wreszcie najcieplejsza i najobszerniejsza o Kaszubach, o tym ludzie, o którym Polska zapomniała, ale który nie zapomniał Polski. Małe ziarna tych wzmianek rozwina się wkrótce obszernymi rozdziałami, opowieściami Wiatru. 
Dotychczas wymienione ziarna są to wyłącznie ziarna tematyczne. Tkwiły już w Wiśle także ziarna ideowe rozwinięte później i rozdmuchane przez Wiatr; tkwiło historiozoficzne ujęcie „stylu” polskiego życia dziejowego: „Naród polski nie prowadził nigdy wojen zaborczych” - „nie pragnie on i nie pożąda niczyjej roli, ani domu, ani siły, ani szczęścia, ani sławy. Pragnie tylko pracy na swojej własnej roli, szczęścia w swym własnym domu, rozwinięcia swej własnej siły i czci dla swojej sławy".

Że to zasadnicze stanowisko wobec dziejów polskich jest także naczelną bazą ideową wielkiej późniejszej opowieści o Pomorzu - przypominać nie trzeba. Ale opowieść o Wiśle oddziałała na wielką książkę Żeromskiego wielokrotnie głębiej, może nawet najistotniej, wykreśliła bowiem główny kierunek ideowy.

Wprawdzie bowiem słuszna jest uwaga, że Wisła w poemacie Żeromskiego nie została ujęta antropomorficznie, ale słuszność ta odnosi się tylko do jednostkowego pojęcia „antropos”. Natomiast zbliżenie obrazu Wisły z obrazem ludu, zbiorowości, a przede wszystkim narodu polskiego jest bardzo częste, jest może nawet podstawą całego utworu. „Jak rzeka Wisła był polski lud czyjś i niczyj, nie swój, bezpański, bezużyteczny" - pisze raz wyraźnie Żeromski, a o parę stron dalej woła: „O Wisło, Wisło. Żywa pieśni lądu polskiego, nigdy nie przerwana wieści o tym, co się dokonało... i uroczy pozwie ku przyszłości bez końca".

Analogie bezpłodnych mielizn, wirów, sobiepańskich wylewów, żmudnego, pracowitego nurtu głównego, uregulowanej w przyszłości drogi idą przez całą książkę, podobnie jak zrywanie zakuć lodowych.

Nade wszystko jednak narzuca się rys główny: ujmowania - poprzez analogie - historycznego bytu narodu, ludu w kategoriach procesów dynamicznych, trwających przez wieki i w kategoriach procesów jakby geologiczno-biologicznych, milczących, bezimiennych, niezindywidualizowanych, masowych, o jednej dominujacej naturze i kierunku.

Tak więc np. zrozumiała jest rzeczą, że pisarz zaczynając swą książkę od czasów pradawnych skłonny był za tło dać puszczę, lasy pierwotne. A w dzikie te bory wpuścił dzikiego zwierza: wilki idące tropem przebiegła gromada, straszliwe tury, niedźwiedzie podbierające miód, jelenie splątane konarami rogów i zdychające na rykowisku, rysie, jastrzębie, a nie zapomniał też o „prześlicznych wywijaniach się skrętów żmii”. (Nie ma łagodnych wiewiórek czy powolnych borsuków i bobrów.) Były one niemalże koniecznym akompaniamentem przy ukazywaniu dziejów pierwotnych, wpółdzikich plemion. A już na pewno były akompaniamentem koniecznym dla poczynań Smętka. Bezlitosny instynkt drapieżców i groza kniej tworzyły odpowiednie ramy dla okrutnych dzieł pomorskiego demona. (Zresztą czasem posługiwał się Żeromski zgrzytem kontrastu np. podczas tańca Smętka na cichej, słonecznej polanie.)

Że jednak groza borów nie łączyła się pisarzowi tylko $\mathrm{z}$ wiekami pradawnymi, a raczej $z$ biegunem zła, albo też ludźmi pewnego typu - świadectwem współczesna nowela o miłości hrabiego von Arffberg. Oto garść określeń parku-lasu in Pommern: „Nad smutnym, ciemnym basenem stały drzewa obumarłe, odarte $z$ listowia. Czarna masa zwartych olbrzymów, straszących ludzi”, (tam kryła się) „nieodgadniona duma, wzgardliwa na wszystko ludzkie obojętność”. A dalej „ostępy sosen tworzyły ciemnicę groźną i milczącą... złowrogie drzewa... odpychająca groza wiała $z$ tej 
głębi czarnej, pełnej tajemnicy”. Nieludzka miłość, żywioł namiętny znalazły ramy surowe i groźne.

Dopiero z obrazem osiadłego życia Słowian w głębi powieści pojawia się przy węgłach domu starego Wyszki „grusza polna, dzika - która się przecie z ludźmi zeszła, zrosła, stowarzyszyła”, a później rzewny obraz sadu przy tym domu, „chorowitej jabłonki” i starej gruszy (i starego psa). W poprzednim fragmencie na jarmarku gdańskim mrowią się gromadami owce i krowy, kury i gęsi. Nienadaremnie przy obrazie ludzi szczególnie bliskich sercu pisarza w tym okresie, tuż przed grożącą im okrutną katastrofą, otacza ich elementami przyrody swojskiej, rolniczej, osiadłej. Te elementy są tym znamienniejsze, że na ogół Żeromskiemu neoromantykowi odpowiada zupełnie odmienny typ przyrody. Tutaj wyraźnie bieguny pewnej koncepcji ideowej przyciagają obrazy sobie bliskie, wbrew skłonnościom estetycznym autora, wbrew także przeważającym skłonnościom dawnym poszukiwania w przyrodzie wytchnienia, łagodności, uroku. (Jedynymi „miękkimi” - a przy tym obszernymi, obrazami cichych motywów są parokrotnie sylwety ptaków, a przede wszystkim najdoskonalszy pewnie fragment opisowy całej książki - niezwykle subtelny, czarujący opis bursztynu, włożonego zresztą zbędnie w ręce Smętka.)

Charakterystyczne, że w tej opowieści, uznanej za pierwszą opowieść o polskim morzu - jest go tam bardzo mało. W pierwszym fragmencie mamy wybrzeże Oksywii, gwoli surowej dzikości pradawnych czasów ukazane w szczególnie okrutnym momencie - w zimie, gdy otchłanie fal szturmują lodowe brzegi. Później spotykamy kilka krótkich tylko napomknień o morzu, a w przedostatnim fragmencie dłuższy obraz jałowej, torfiastej równiny Gdyni i budującego się portu, w ostatnim wreszcie brzeg ledwie migoce światełkami w noc księżycową. Wizja przelewających się odmętów oglądana z łodzi podwodnej dotyczy już Morza Północnego.

I morze polskie, i jego brzeg nie pojawiły się jeszcze w tej książce. To dopiero wiatr od morza ciagnący przez puszcze, łąki i jeziora (zawsze malowane ze szczególnym urokiem), przez wzgórza Pomorza, Kaszubskiej Szwajcarii i delty Wisły.

Natomiast Wisła, która przewija się kilkakrotnie w migawkowych uwagach, raz daje pełniejsze „zbliżenie” krajobrazowe, kiedy św. Wojciech z towarzyszami przeprawia się na stronę pruska. A później dwa razy w opowieści o Janie z Kolna podpłynie nurtem symbolicznym, tak dobrze znanym $z$ małej książeczki-poematu wydanej trzy lata wcześniej. „Kochał tę rzekę wieczystą, obraz pędu bez początku i końca... niestrzymanej wędrówki daleko... pęd siły wiekuistej i wiekuistego dążenia naprzód - naprzód. Ta rzeka - obraz czasu, który również tylko w ruchu istnieje”. Trudno o pełniejsze podkreślenie po latach dawnej wizji, owego „wieczne - dalej".

Przeżycia związane z morzem i wybrzeżem polskim znalazły sobie ujście w twórczości Żeromskiego dopiero w książce Międzymorze, opisowej jak Wisła, choć zbudowanej odmiennie. Wśród trzydziestu fragmencików część daje małe, kolorystycznie ujęte krajobrazy o różnych porach dnia i nocy, część - migawkowe zdjęcia z pointą refleksji, część drobne rozprawki geologiczne czy historyczne (bardzo oschłe), a jest tam i opowieść-nowela o braciach Kąkolach. Mimo seryjność w ugrupowaniu większości fragmentów trudno w tym luźnym notatniku czy szkicowniku odkryć nić przewodnia, a choćby główny kierunek. Przy tym prócz momentów szarpiących nerwy (tak właściwych kiedyś Żeromskiemu) w nowelce o Kąkolach 
w reszcie książki dominuje spokojna opisowość, skłonna do refleksji, często o zabarwieniu elegijnym.

Część refleksji idzie śladem Wiatru od morza, jak choćby zakończenie całej książki: „Nie przynosimy tu zbrodni... przemocy... krzywdy. Przynosimy zapomnienie, odpuszczenie i pokój. Przynosimy dobro i pracę". Jest to potwierdzenie sformułowań historiozoficznych poprzedniej książki.

Tak samo w innym fragmencie Żeromski - mimo cały mrok władztwa nocy, rozpętania się mąk duszy i marzeń o wyłamaniu zagród otaczających naturę człowieka - sławi przecież dzień, syna słońca, ,zdrowego bożyca, wcielonego w ducha ludzkiego, wszystkowidzący i wszechwładnący rozum" - łatwo przypomina się potępienie „nieludzkich” podszeptów Smętka. W szerszym jednak sensie mamy tu odwrót od pierwiastków dionizyjskich do apollińskich. I może nieprzypadkowo łączy się tu refleksyjność wielu opisów $z$ apoteozą rozumu, tak różniąc się od spokojnie twórczego biologizmu zbiorowości.

Najbardziej jednak różni się inny motyw. Patrząc na morze, słońce i wiatr, dające zdrowie i siłę, po które chciałby wysyłać tysiącami „dzieci skarlałe w miast zaułkach, w proletariackich piwnicach", pisarz wybucha żalem i gniewem nad swą bezsilnością. „Muszę patrzeć - pisze - jak pycha bogaczów, spryt kanalii i dorobkiewiczów wszystko w Polsce zamieniając na kawał - po staremu wzdłuż i wszerz rozbija się i hula".

Ostry krytycyzm wobec odrodzonej Polski współczesnej, zgrzyt niecierpliwości wyraźnie ukazują na budzenie się publicystycznych, gorzkich refleksji jeszcze z wojennych Biczów z piasku czy Organizacji inteligencji, a co ważniejsze - ukazuja, że już niedaleko, już o krok - Przedwiośnie.

Tak zatem dwa utwory opisowe: Wista i Międzymorze, jak prolog i epilog otwierają i zamykają okres twórczości Żeromskiego z pierwszych lat powojennych Polski, okres przepojony spokojną pogodą i ufną w przyszłość siłą, niedługi okres, którego najdojrzalszym owocem jest - Wiatr od morza.

Że zasadniczym przeżyciem, które kształtowało wówczas dzieła Żeromskiego było zmartwychwstanie Polski po stuletniej niewoli - nie trzeba udowadniać. Niezwykły wynik okrutnej wojny, że wszyscy trzej mocarze-zaborcy, walcząc ze sobą, razem nagle upadli, że tryumfowała słuszna sprawa wyrosła $z$ upartego, heroicznego trwania narodu przez kilka pokoleń, że Polska wracała na swe dziejowe miejsce - musiał napoić serce pisarza optymizmem. Po wyjściu z ciemnicy najpierw uderza blask, ciepło i świeżość dnia; cienie zauważą się później.

Nie dziw zatem, że po majestatycznym obrazie Wisły, dochodzącej wreszcie do morza, ukazał pisarz stopniowe wypieranie zła z ziemi polskiej przez cierpliwy, pracowity nurt wielu pokolen, wyrastających z rolnego, osiadłego typu życia, że zło utraciło charakter wieczysty i niezwalczony, a przyroda dzika i groźna ustąpiła pierwszego miejsca uczuciowego obrazom natury swojskiej, rolniczo-hodowlanej. Pewna koncepcja ideowa dominowała. Wszystkie większe całostki i drobne opiłki dzieła układały się wzdłuż elektromagnetycznych linii głównego prądu, jaki płynął przez pierś Żeromskiego w tych latach, w pierwszych latach odrodzonej Polski.

Ten prąd ideowy, ta ufność w szczęśliwe wyniki drobnych, stopniowych, powolnych osiągnięć zbiorowości, opartej o zbożną pracę i dobrą wolę wielu pokoleń, 
ta wpół biologiczna wiara w zdrowy rozwój uczciwego życia zachwiała się w okresie Przedwiośnia. W tej ostatniej powieści ideologię czterech poprzednich lat Żeromskiego reprezentuje Gajowiec swym programem drobnych ulepszeń życia w Polsce, przeprowadzanych oszczędnie, swojsko, sposobem gospodarczym. Ale Baryka go nie słucha.

Tak rozpływa się ostatnia fala wywołana kiedyś przez nurt Wisły. Baryka już jej słuchać nie chce.

\section{Abstract \\ TADEUSZ MAKOWIECKI'S CRITICAL UNPUBLISHED PAPERS}

Edited by

KRYSTYNA JAKOWSKA University of Białystok

Tadeusz Makowiecki's four literary critical texts found in his archive files are published here for the first time. They were composed after the WWII, before his death in 1952. Their present publication is preceded by an attempt to describe the characteristic features of Makowiecki's entire, also interwar, critical writing; the writing which to date in this aspect has been neither researched nor described, in contrast to his often recollected and presently enjoying great interest academic achievements.

Makowiecki jointly created the personalistic trend in criticism of the 1930s. In the language of his studies and sketches a discrete and precise analysis was subject to picture with architecture, musical or painting metaphor. The image in the criticism organises the line of reasoning, and sometimes replaces conclusion. The imagery, connected with excellent free style forms a critical idiom of high literary value. 